\title{
Polychæta of Plymouth and the South Devon Coast, including a list of the Archiannelida.
}

\author{
By \\ E. J. Allen, D.Sc., F.R.S., \\ Director of the Plymouth Laboratory. \\ INTRODUCTION.
}

THE present list of Polychætes is a revision of the list published in 1904, as part of the general list of the Plymouth Marine Invertebrate Fauna (Journ. Mar. Biol. Assoc., vol. vii., 1904, p. 219). It is the result of work carried on in the intervals of other researches, as opportunity offered, and there are in all probability a good many gaps still to be filled.

To the Plymouth records I have added those obtained at Salcombe (Journ. Mar. Biol. Assoc., vol. vi., 1900, p. 151) and at Exmouth (ditto, vol. vi., 1902, p. 295), a few records from the Teignmouth estuary, and Major Elwes' records from Torquay (Journ. Mar. Biol. Assoc., vol. viii., 1908, p. 197, and 1909, p. 347 ; vol. ix., 1910, p. 59), the latter dealing only with Polychætes found on the shore. Mr. Crawshay's records, from the valuable series of dredgings S.S.W. of the Eddystone to fifty fathoms, have also been included (Journ. Mar. Biol. Assoc., vol. ix., 1912, p. 339).

Apart from the Archiannelids there are comparatively few species in the list which I have not been able to examine myself. In all cases where no initials appear at the end of a paragraph the responsibility for the record is my own.

My thanks are due to Major Elwes for a number of mounted specimens of the Torquay species, which have been of great help, especially with the Syllidæ.

As regards nomenclature, after the name of each species, one or more references have been given to papers where a detailed description of the species intended is given. Whilst endeavouring as far as possible to make use of that name which will probably stand, elaborate discussions of nomenclature and synonymy have been in general avoided. The main object has been to make quite clear which form is intended. Considerable changes in the names used in the former list have been necessary, since our knowledge of the British Polychæte fauna has been greatly extended by the publication of several parts of Prof. McIntosh's 
Monograph, and of important papers on Irish Polychætes by Mr. R. Southern. The character of the various dredging and trawling grounds in the Plymouth neighbourhood is fully described in the general account of the Plymouth Fauna (Journ. Mar. Biol. Assoc., vol. vii., 1904, p. 159), where a chart of the area will also be found. Similar accounts of the Salcombe and Exmouth areas will be found in the respective reports.

The following list of the Plymouth grounds, with depth and general nature of the bottom, etc., may be useful for reference.

\section{LIST OF PLYMOUTH COLLECTING GROUNDS.}

\section{Shore.}

Rum Bay. This term is used to include the shore from Batten Breakwater to Jennycliff Bay. Shale rocks, with patches of gravel and sand. Some stony ground.

Drake's Island. Stony and rocky shore. Some patches of sand and a zostera-bed.

Mount Edgcumbe. At the mouth of the Hamoaze. Very similar to the rocky and stony ground on Drake's Island.

Rocks below Laboratory. Rocks of hard Plymouth limestone, with good rock-pools.

\section{Dredging Grounds of Plymouth Sound.}

Millbay Channel. 14-23 fms. Stones and mud. Free from growth of seaweeds.

Asia Shoal. 5-7 fms. Stony ground with some growth of red seaweeds.

Queen's Ground. 5-6 fms. The term is used to include the area from Queen's Ground Buoy to New Grounds Buoy and the ground around the latter, all situated at the western entrance to Plymouth Sound. The soil is shell gravel, with stones and shells. It is very free from mud and there is some growth of red seaweeds.

Duke Rock. 4-5 fms. Near the eastern entrance to Plymouth Sound. The bottom is rocky, with intervals of ground occupied by stones and shells.

The Cattewater. The inner Plymouth harbour, where the bottom is soft mud, which can be worked with a shrimp trawl. The trawlers often throw their refuse overboard here, and many of the outside species can survive for a time. 


\section{THE YEALM ESTUARY.}

A sheltered estuary to the east of Plymouth, where a large body of pure sea-water extends for a considerable distance from the mouth, and the fauna is essentially marine.

\section{OUTSIDE GROUNDS.}

\section{Shores.}

Wembury Bay. A rocky shore, with intervals of sand. Some of the reefs give considerable shelter from the breakers, especially at the western side of the bay.

Reny Rocks. A reef of exposed, weed-covered rocks running from the Shagstone to the mainland.

Whitsand Bay. An exposed shore which consists chiefly of fine, shifting sand, with occasional rocky patches.

\section{Dredging and Trawling Grounds.}

Cawsand Bay. Depth 3-5 fms. An inshore, shallow, sheltered bay with a bottom of fine sand.

Whitsand Bay. Depth 4-8fms. A shallow sandy bay, more exposed than Cawsand Bay.

Mewstone Ledge. Depth 10-15 fms. A ridge of soft red, conglomerate rock, free from growth of seaweed. The dredge breaks off portions of the rock.

Mewstone Shell Gravel and "Amphioxus" Ground. Depth 10-12 fms. Bottom of clean shell gravel.

Stoke Point Grounds. Depth 10-22 fms. Reefs of red conglomerate alternating with patches of gravel and sand.

Rame-Eddystone Grounds. Depth 25-30 fms. Trawling ground between Rame Head and the Eddystone. Bottom muddy gravel, with clean sand in places.

Looe-Eddystone Grounds. Depth 25-30 fms. An extension westwards towards Looe of the Rame-Eddystone Grounds. Bottom similar to that of the latter, but rougher.

Eddystone Grounds. Depth 28-35 fms. Bottom varied. They are fully described in this Journal, vol. v., p. 365. 


\section{EXPLANATION OF INITIALS.}

The authorities for various records are indicated by their initials, a list of which is given below. Initials have reference only to the paragraph in which they stand. Where no initials are given at the end of any paragraph the records are by E. J. Allen :-

A.J.S.-A. J. Smith, Assistant at the Laboratory since 1895.

c.s.-Creswell Shearer.

E.J.A.-E. J. Allen.

E.J.B.-E. J. Bles.

F.w.G. - F. W. Gamble.

J.T.C.-J. T. Cunningham.

R.A.T. - R. A. Todd.

S.P.-S. Pace.

T.v.H. -T. V. Hodgson.

w.B.B. - W. B. Benham.

w.G.-Walter Garstang.

\section{ARCHIANNELIDA.}

Turbanella hyalina Max Schultze: Muller's Archiv., 1853, p. 241.

Plymouth. Found by Dr. C. Shearer on the glass of one of the Laboratory tanks, July 26th, 1909. Dr. Shearer states:- "This form is apparently most rare, having never been described since 1853. Apparently an Archiannelid with parapodia of a primitive kind. Usually placed in the Gastrotrichia."

Dinophilus tæniatus Harmer: Journ. Mar. Biol. Assoc. N.S. vol. 1, p. 119.

Plymouth. In rock-pools in the Sound far above low water, in March and April, not found in June (Harmer, loc. cit.). Found often in immense numbers in pools high up on the limestone rocks below the Laboratory and in front of West Hoe Terrace. Records of the occurrence of the species below the Laboratory were kept by Mr. A. J. Smith between 1906 and 1910. From these it appears that it was abundant from November to April, but absent or very scarce between May and October.

Dinophilus gyrociliatus Schmidt: Shearer, Quart. Journ. Micr. Sci. vol. 57,1912 , p. 337.

Plymouth. From sandy dredgings from Cawsand Bay. Can also be obtained in scrapings from the piles in Millbay Docks. Lived well in small aquaria and became established in the Laboratory tanks (Shearer, loc. cit., p. 342).

Breeds all the year round in the Laboratory Tanks (c.s.).

Protodrilus flavocapitatus Uljanin : Pierantoni, Protodrilus. Fauna Flora Golf. Neapel. Mon. 31, 1908, p. 167.

Plymouth. The first record of Protodrilus at Plymouth is by 
Bles (Jour. M.B.A., vol. 2, 1892, p. 343) who reared it from townettings taken in September. He considers the species to be P. Leuckartii Hatschek (Arbeit. Zool. Inst. Wien., vol. 3, 1880, p. 79).

Adults have since been found on the shore in numbers by Orton (Nature, vol. 91, 1913, pp. 85 and 348) at eleven different points between Salcombe and Looe, under stones and gravel near high-water mark, where small fresh-water streams join the sea. Orton records this species as $P$. flavocapitatus Uljanin.

Ctenodrilus pardalis Claparède: Beobactungen über Anat. u. Entw. wirbellos. Thiere a. d. K. von Normandie, 1863, p. 25.

Plymouth. Found in the Laboratory tanks and also in pools at high-tide level below the Laboratory by Dr. C. Shearer. Some years it is very abundant in the tanks, in other years it is absent (c.s.).

Nerilla antennata Schmidt: Goodrich, Quart. Journ. Micr. Sci. vol. 57, 1912, p. 397.

Plymouth. First recorded by Miss F. Buchanan (Rep. Brit. Assoc. 1892 , p. 358). It has since been found to occur frequently in the Laboratory tanks, and also in scrapings from piles in the Cattewater.

Breeds from February to June in the Laboratory Tanks (c.s.).

SaccocinRus sp.: Goodrich, Quart. Journ. Micr. Sci. vol. 44, 1901, p. 413 ; and Pierantoni, Ann. Mus. Zool. Napoli, vol. 2, no. 18, 1907.

Plymouth. Found by Orton in Cawsand Bay together with Protodrilus, amongst stones and gravel just below high-water mark where a small fresh-water stream joins the sea. He thinks the species different from S. papillocercus Bobretzky (Nature, vol. 91, 1913, p. 348$)$.

Polygordius Lacteus Schneider: Hempelman, Zeitsch. wiss. Zool. vol. 84,1906 , p. 527.

Plymouth. Dredged in clean shell gravel off the Mewstone and near the west end of the Breakwater. In clean shell gravel near the Eddystone and off Bolt Head.

Histriobdella homari van Beneden: Foettinger, Archiv. Biologie, V. 1884, p. 435. Shearer, Quart. Journ. Micr. Sci. vol. 55, 1910, p. 287.

Plymouth. Usually found on the eggs of lobsters taken by fishermen, but normally an inhabitant of the branchial chamber (c.s.).

Breeding during the summer months.

Breeding in September (c.s.). 


\section{POLYCH正TA.}

\section{SYILID年。}

Exogone gemmifera Pagenstecher: McIntosh, Mon. Brit. Ann. II. 1, 1908, p. 151.

Plymouth. Common on the shore amongst the roots of Laminaria and other weeds, in the Sound and on the coast outside. Frequent in dredgings from the Sound. It also occurs in dredgings from deeper water, e.g. 2 miles off Yealm Point in $15 \mathrm{fms}$. and off the Eddystone in $30-35 \mathrm{fms}$.

Breeding: A number of specimens found amongst Ascidians from the piles in Millbay Dock in June carried eggs and embryos in different stages of development.

Torquay. Not uncommon amongst sea-weeds from half-tide mark downwards (Elwes, Journ. M.B.A., vol. 8, 1908, p. 197).

Sph жrosyluis hystrix Claparède: McIntosh, Mon. Brit. Ann. II. 1, 1908, p. 157.

PLYMouth. Frequent in dredgings from the Sound; occasional specimens amongst roots of weeds from the shore.

SpH жRosyllis ovigera Langerhans : Wurmfauna v. Madeira, Zeitschr. Wiss. Zool. XXXII. 1879, p. 567.

Plymouth. In the Sound near New Grounds Buoy. Several specimens have been taken.

The species seems to be quite distinct from $S$. hystrix as well as from S. pirifera, Claparède. The palps are very broad and the median tentacle is in a line with or more generally in front of the anterior eyes, as figured and described by Langerhans. The body is always coated thickly with sand and mud, which enables the specimens to be separated at once from the S. hystrix found in the same material. The body is covered with papillæ.

Sph zrosyllis erinaceus Claparède, var. : de St. Joseph, Ann. Polych. .Dinard; Ann. Sci. Nat. Zool. 1886, p. 207.

Plymouth. Common amongst roots of Laminaria from Rum Bay.

The specimens differ from the descriptions and figures of Claparède and de St. Joseph in having the two anal cirri large and much swollen at the base.

Breeding: A specimen obtained in June had four large eggs on each segment from Segt. 9 backwards. The eggs were carried on the dorsal side of the segment. On the segments anterior to Segt. 9, four round tubercles were present on each, in positions corresponding to those occupied by the eggs. 
Grubea clavata, Claparède: Beobactungen, p. 41. Pl. XIII. Figs. 28-29. de St. Joseph, Ann. Sci. Nat. Zool. I. 1886, p. 200.

Plymouth. From Laminaria roots, Rum Bay shore.

Torquay. One example from Laminaria root, Oddicombe Beach (Elwes, Journ. M.B.A., vol. 8, 1908, p. 197).

Grubea limbata Claparède: Ann. Chètop. Naples, p. 208. Viguier : Arch. Zool. Exp. II. 1884, p. 103.

Plymouth. From Laminaria roots from the Breakwater and Reny Rocks. Dredged near the east end of the Breakwater in 4 to $5 \mathrm{fms}$.

Four specimens have been obtained altogether, one in June with long swimming bristles. The specimens agree in all respects with the descriptions of Claparède and Langerhans. The buccal segment is hidden by a raised collar similar to that seen in Eusyllis.

Grubea pusilla Dujardin: Langerhans, Zeitschr. Wiss. Zool. XXXII. 1879, p. 565. de St. Joseph, Ann. Sci. Nat. Zool. I. 1886, p. 203.

Plymouth. Amongst the roots of Laminaria from Rum Bay.

Breeding: Two females with embryos on the parapodia were seen in March.

Pionosyllis lamelligera de St. Joseph: Ann. Sci. Nat. Zool. I. 1886, p. 163.

Plymouth. In dredgings from Duke Rock, New Grounds, between Knap and Panther Buoys, and Mewstone Ledge. Amongst Laminaria roots from Reny Rocks.

ToRqUay. Very common in Laminaria roots (Elwes, Journ. M.B.A., vol. 8, 1908, p. 198).

Pionosyllis divaricata Keferstein : McIntosh, Mon. Brit. Ann. II. 1, 1908, p. 164. de St. Joséph, Ann. Sci. Nat. Zool. I. 1886, p. 160 as $P$. longocirrata.

Plymouth. One specimen from dredgings from New Grounds.

Torquay. Three or four specimens from Corbyn's Head (Elwes, Journ. M.B.A., vol. 8, 1908, p. 198).

Eusyluis tubifex (Gosse): McIntosh, Mon. Brit. Ann. II. 1, 1908, p. 173. (Probably the same as E. Blomstrandi, Malmgren as described by de St. Joseph, Ann. Sci. Nat. Zool. I. 1886, p. 171. Cf. Southern, Clare Island Survey, Pt. 47, Proceed. Roy. Irish Acad. XXXI. 1914, p. 32.)

Plymouth. Very common in the Sound from the shore and in dredgings. Often met with in dredgings from outside, e.g. Mewstone Ledge and Eddystone Grounds.

Breeding: Females with ova and swimming bristles recorded in February and March.

Torquay. Fairly common amongst weeds covered with Polyzoa and Sertularia (Elwes, Journ. M.B.A., vol. 8, 1908, p. 198). 
Breeding: Females with ova, some with well developed swimming bristles, in April.

Eusyllis monilicornis Malmgren: de St. Joseph, Ann. Sci. Nat. Zool. I. 1886, p. 169 (cf. Langerhans, Wurmfauna von Madeira, Zeits. Wiss. Zool. XXXII. 1879, p. 551).

Plymouth. Single specimens have been taken on a number of occasions from dredgings in the Sound, at Duke Rock and Asia Shoal. One from Mewstone Ledge.

The species is clearly distinguished from $E$. tubifex (Gosse) by its more robust form, and by the character of the setæ, the end pieces of which are of two kinds in each typical foot, the one short and stout, the other long and slender. The hinder part of the head generally carries a conspicuous patch of dark brown or black pigment.

Eusyllis lamelligera Marion and Bobretzky: Annélides du Golfe de Marseille, Ann. Sci. Nat. $6^{e}$ sér. II. p. 33. Pl. III. Fig. 9. de St. Joseph, Ann. Sci. Nat. Zool. I. 1886, p. 169.

Plymouth. Two or three specimens have been obtained from dredgings from Mewstone Ledge and Eddystone Grounds.

Breeding: A female with nearly ripe eggs was taken in July.

A well defined species, which can easily be recognised by the enlarged leaf-like shape of the first pair of ventral cirri. It is well described by Marion and Bobretzky.

Odontosyluis ctenostoma Claparède: McIntosh, Mon. Brit. Ann. II. 1, 1908, p. 182.

Plymouth. Very abundant on the shores of the Sound and frequent in dredgings from the Sound.

Breeding: A specimen in the swimming stage, with long setæ, was recorded in May.

Torquay. The most abundant of all the species of Syllids (Elwes, Journ. M.B.A., vol. 8, 1908, p. 199).

Odontosyllis fulgurans Audouin and Edwards: McIntosh, Mon. Brit. Ann. II. 1, 1908, p. 179.

Plymouth. Dredged at Queen's Ground (New Grounds), Mewstone Ledge, off Stoke Point and on Rame Eddystone Grounds. Usually not more than one specimen on each occasion.

Odontosyluis gibBA Claparède: McIntosh, Mon. Brit. Ann. II. 1, 1908, p. 183.

Plymouth. Common in dredgings from Asia Shoal, Duke Rock, Queen's Ground and Millbay Channel.

Torquay. Several examples were found at Corbyn's Head (Elwes, Journ. M.B.A., vol. 8, 1908, p. 199).

Trypanosyllis zebra (Grube): McIntosh, Mon. Brit. Ann. II. 1, 1908, p. 169. 
Plymouth. Frequent in dredgings from Millbay Channel and Asia Shoal. Occasionally from other parts of the Sound. Yealm dredging. On the shore at Wembury Bay in a mass of yellow sponge.

ToRquaY. Fairly numerous among Laminaria roots from the rocks between Babbacombe and Oddicombe beaches (Elwes, Journ. M.B.A., vol. 8, 1908, p. 200).

Trypanosyllis caeliaca Claparède: McIntosh, Mon. Brit. Ann. II. 2, 1910 , p. 240.

Torquay. Four or five specimens from Oddicombe Rocks (Elwes, Journ. M.B.A., vol. 8, 1908, p. 201).

Eurysyluis paradoxa (Claparède): McIntosh, Mon. Brit. Ann. II. 2, 1910, p. 241.

Plymouth. Occasional specimens from Asia Shoal dredgings and from dredgings on the rocky ground south of the Breakwater. One or two from Laminaria roots from the shore at Reny Rocks.

Breeding: A specimen with hinder segments swollen with genital products from Reny Rocks in July.

Torquay. From Oddicombe, Corbyn's Head and Livermead (Elwes, Journ. M.B.A., vol. 8, 1908, p. 201).

Syllis (typosyllis) armillaris (Müller): McIntosh, Ann. Mag. Nat. Hist. Ser. 8. vol. xi, 1913, p. 83. McIntosh, Mon. Brit. Ann. II. 1, 1908 , p. 188 ; ditto II. 2, 1910, p. 238.

Plymouth. Eddystone Grounds (Weldon, Journ. M.B.A., vol. 5, 1899, p. 481). A number of specimens from 20 to 50 miles S.S.W. of Eddystone in 42-49 fms. (L.R.c.). Frequent on all dredging grounds in and around Plymouth Sound. Amongst Ascidians from Millbay Dock. Occasional specimens from the shore.

The species was included in former lists (Journ. M.B.A., vol. 7, 1904, p. 219) as Typosyllis alternosetosa, de St. Joseph.

Torquay. Fairly common. Recorded as Typosyllis alternosetosa (Elwes, Journ. M.B.A., vol. 8, 1908, p. 199).

Syllis (Typosyllis) PRolifera Krohn: Langerhans, Zeit. wiss. Zool. XXXII, 1879, p. 530. Claparède, Glanures Zoot. parmi les Annél. de Port-Vendres. 1864, p. 70 (530) as Syllis Armandi. McIntosh, Mon. Brit. Ann. II. 1, 1908, p. 167 as Pionosyllis hyalina Grube and possibly in part, p. 161 as Pionosyllis prolifera Krohn.

Plymouth. Common everywhere amongst weeds, etc., on the shore, as well as in dredgings from shallow water especially in Plymouth Sound.

Torquay. One of the most numerous of the Torquay Syllids. A very variable species (Elwes, Journ. M.B.A., vol. 8, 1908, p. 199).

There is some difficulty in deciding the correct nomenclature and 
synonymy of the three forms of Syllis which have been described by different authors under the names, Syllis protifera Krohn, S. variegata Grube and S. hyalina Grube. After examining a considerable number of living specimens my own view is that two distinct species have been referred to under these names, which would most conveniently and probably according to the law of priority most correctly bear the names S. prolifera Krohn and $S$. variegata Grube. The name S. hyalina Grube has I think most frequently been applied to examples of $S$. prolifera (and possibly other species) which were not yet fully grown.* In S. prolifera Krohn the pharynx is comparatively short and stout, the single dorsal tooth is large and is usually situated at the hinder end of the first third of the pharynx. There is a considerable distance between the point of the tooth and the anterior edge of the pharynx.

The proventriculus is comparatively short and stout, being about the same length as the pharynx.

The end pieces of the bristles have very boldly bifid tips, the bifid character becoming more and more marked in the posterior segments, where the end pieces also become much shorter.

In the last few parapodia there is in each a single straight simple bristle dorsally, the tip of which is often with some difficulty seen to be bifid, and ventrally a single curved simple bristle with a boldly bifid tip exactly resembling the tip of the compound bristles.

The anterior segments contain a quantity of brown pigment on the dorsal surface. This pigment is in many specimens distributed fairly uniformly over the surface, but more generally it tends to accumulate along the posterior border of the segment forming a transverse brown bar. In other specimens again in addition to this posterior bar there is an accumulation of the pigment in the centre of the dorsal surface of the segment, a brown patch above each of the dorsal cirri, and a bar along the anterior border of the segment. The pattern thus formed tends to resemble that of $S$. variegata, but this pattern is not often found in $S$. prolifera, in which the uniform distribution of pigment on the dorsal surface with a posterior brown bar is the more characteristic condition.

The dorsal cirri are moniliform. They are distinctly long, as compared for example with $S$. armillaris or $S$. gracilis, and in wellgrown worms have from 25 to 30 or even 40 articulations. They differ in length, being alternately long and short throughout the greater part of the body.

The Pionosyllis hyalina Grube described by McIntosh (Mon. Brit. Ann. II. 1, 1908, p. 166) is almost certainly this form in an immature condition, with the cirri not yet fully grown and thus having fewer articulations.

* It should be noted that the S. hyalina of Malaquin is the S. alternosetosa de St. Joseph, recorded in the present list as S. armillaris (Müller) (Rech. sur les Syllidiens, 1893, p. 96).

NEW SERIES.-VOL. X. NO. 4. MAY, 1915. 
The corresponding characters of $S$. variegata are described below under that species.

Syllis (typosyllis) variegata Grube: Langerhans, Zeit. wiss. Zool. XXXII, 1879, p. 532, Marenzeller, Sitzb. mathem.-naturw. Cl. LXIX. Bd. I. 1874, p. 441. McIntosh, Mon. Brit. Ann. II. 1, 1908, p. 161 as Pionosyllis prolifera (Krohn).

Plymouth. Not uncommon in dredgings from Millbay Channel and Asia Shoal. Off Yealm Head. One large specimen from the shore at Wembury Bay amongst Laminaria roots.

South by west of Eddystone in 44-49 fms. (Crawshay, Journ. M.B.A., vol. 9,1912 , p. 340 ).

The distinction between $S$. variegata and $S$. prolifera will be seen on comparing the following characters. In S. variegata Grube the pharynx is long and slender, extending through as many as ten segments when a fully grown worm is alive and crawling. The single dorsal tooth is relatively smaller than in $S$. prolifera and lies close to the anterior margin of the pharynx.

The proventriculus is long and relatively narrower than in $S$. prolifera.

The end-pieces of the bristles are on the whole longer than those of S. prolifera and are much less boldly bifid at the tip. The long end-pieces are continued back to the posterior segments to a much greater degree than in $S$. prolifera and the bifid character does not to the same extent become more marked.

Simple bristles occur in the posterior parapodia as in the former species. Their bifid character is not easy to make out, but some of the bristles seem to show it under a high power of the microscope.

The pigment is brown and the transverse figure of eight pattern described by Grube and subsequent authors is very characteristic on the anterior segments. This pattern is liable to considerable modification, one extreme form of which is described and figured by McIntosh (p. 162, fig. 53). It will be seen that merely by thickening the different bars and dots figured by McIntosh until their ends touch the characteristic variegata pattern is produced. The largest specimen of $S$. variegata which I have examined resembles McIntosh's description in colour pattern as well as in all other respects.

The dorsal cirri are moniliform and long, in most cases longer than in $S$. prolifera. In a large specimen the median tentacle contained about 42 articulations, whilst the lateral contained 20. The dorsal cirri along most of the length of the body are alternately long and short ; in the specimen referred to there were 43 articulations in the long cirri and 20 in the short ones. The short cirri are carried by the worm horizontally, whilst the long ones rise vertically and arch over the back, the ends being frequently coiled. The long and short cirri are of nearly uniform diameter throughout, thus differing from Syllis Krohnii Ehlers. 
Syldis (typosyllis) Krohnir Ehlers: McIntosh, Mon. Brit. Ann. II. 1, 1908, p. 192.

Plymouth. Amongst Corallina from Rum Bay, and from under a stone at Wembury Bay.

Breeding: A specimen from Wembury Bay in March had a welldeveloped stolon with four red eyes.

Torquay. Amongst Corallina from Corbyn's Head (Elwes, Journ. M.B.A., vol. 8, 1908, p. 200).

Syllis (ehlersia) cornuta Rathke: McIntosh, Mon. Brit. Ann. II. 1, 1908, p. 200.

Plymouth. Eddystone Grounds (Weldon, Journ. M.B.A., vol. 5, 1899, p. 481). Occasional specimens which I believe belong to this species have been obtained from dredgings from Duke Rock, Queen's Ground and Asia Shoal, but the identification is not quite certain.

Syluis Gracilis Grube: McIntosh, Mon. Brit. Ann. II. 1, 1908, p. 203.

Pцyмоuth. Dredgings from Millbay Channel, Asia Shoal and Queen's Ground. Single specimens frequently met with. Rum Bay shore, from crevices of shale.

Syllis (haplosyllis) spongicola Grube: McIntosh, Mon. Brit. Ann. II. 1, 1908, p. 197.

Plymouth. Occasional specimens have been found in dredgings from Plymouth Sound (Millbay Channel, Winter Shoal, Cawsand Bay). A considerable number of specimens were obtained from a mass of slimy sponge dredged on the Mewstone Ledge.

Salcombe. In dredgings from the channel between Salstone and Snape's Point (Journ. M.B.A., vol. 6, 1900, p. 190).

Torquay. Fairly abundant (Elwes, Journ. M.B.A., vol. 8, 1908, p. 199).

Amblyosyllis lineata Grube: McIntosh, Mon. Brit. Ann. II. 1, 1908, p. 225. de St. Joseph, Ann. Sci. Nat. Zool. I. 1886, p. 187 as Pterosyllis (Gattiola) spectabilis Johnston.

Plymouth. Common in dredgings from Millbay Channel: less numerous Queen's Ground, Mallard and Asia Shoal (E.J.A., R.A.T., т.v.н.): sometimes in large numbers in sponges from Millbay Ch. (w.G.). Occurs also amongst Laminaria roots from the shores of the Sound, in dredgings from outside the Breakwater, off Yealm Head and occasionally on Eddystone Grounds.

Salcombe. Dredged in the channel west of Salstone (Journ. M.B.A., vol. 6, 1900, p. 190).

Torquay. In weeds from rocks between Oddicombe and Babbacombe (Elwes, Journ. M.B.A., vol. 8, 1908, p. 199).

It seems probable that Claparède's Pterosyllis formosa is the species under consideration. Both McIntosh and de St. Joseph appear to take this view though neither adopts Claparède's name, which has priority. 
Autolytus longiferiens de St. Joseph: Ann. Sci. Nat. Zool. vol. 1, 1886, p. 217. McIntosh, Mon. Brit. Ann. II. 2, 1910, p. 245. Southern, Proceed. R. Irish Acad. XXXI. 47, p. 39.

Plymouth. Two specimens were dredged on rocky ground immediately south of the Breakwater in May, one from Duke Rock in June and one was found amongst roots of Laminaria from Rum Bay in June.

The male (Polybostricus) and female (Sacconereis) forms of this species were obtained in townets near the Eddystone in February. From one Sacconereis kept in the Laboratory the young hatched two weeks after the specimen was procured.

Torquay. Five or six specimens were obtained on the shore (Elwes, Journ. M.B.A., vol. 8, 1908, p. 202).

Autolytus rubropunctatus (Grube): Marion and Bobretzky, Ann. Golfe Marseille, 1875, p. 44 as Autolytus (Procerca) ornatus. Southern, Proceed. R. Irish Acad. XXXI. 47, 1914, p. 40.

Plymouth. Frequent in dredgings from the Sound, Asia Shoal, Queen's Ground and Duke Rock. Frequent also on all the dredging and trawling grounds between Plymouth and the Eddystone and westwards to Looe.

Breeding: No specimens with stolons were found amongst a large number examined between January and June. At the beginning of July, one specimen was seen with a stolon just beginning to form. The observations were interrupted after that month.

Southern has pointed out that the description given by McIntosh (Mon. Brit. Ann. II. 1, p. 186) does not agree with that of other observers. The Plymouth specimens have no ventral cirrus and the setæ have the typical bifid end-pieces of the genus Autolytus. McIntosh's coloured figure is stated to be from a Plymouth example.

Autolytus pictus (Ehlers): McIntosh, Mon. Brit. Ann. II. 1, 1908, p. 211.

Plymouth. Frequently met with in dredgings from all grounds in Plymouth Sound; especially common amongst Alcyonidium and sponges from Asia Shoal. Occasional specimens on all grounds between Plymouth and the Eddystone, especially on rough ground.

Breeding: Three specimens with the Polybostricus head just commencing to form were found in dredgings from Asia Shoal in April.

Torquay. Rather common on the shore (Elwes, Journ. M.B.A., vol. 8, 1908, p. 201).

Autolytus macrophthalma (Marenzeller): de St. Joseph, Ann. Sci. Nat. Zool. I. 1886, p. 226. Southern, Proc. R. Irish Acad. XXXI. 47, 1914, p. 41.

Plymouth. Specimens have been obtained in dredgings from Millbay Pit, Asia Shoal, New Grounds, Tinker Buoy, and 1 mile off Rame Head. 
Torquay. Two examples from the shore at Babbacombe (Elwes, Journ. M.B.A., vol. 8, 1908, p. 201).

Autolytus ehbiensis de St. Joseph: McIntosh, Mon. Brit. Ann. II. 2, 1910, p. 243. de St. Joseph, Ann. Sci. Nat. Zool. I. 1886, p. 228.

Plymouth. From Laminaria roots and sea-weeds from the shore at Rum Bay, and amongst Ascidians, etc., from Millbay Dock. Dredged off Yealm Head and near the Eddystone.

Breeding: Specimens with chains of buds in January, in February and in April.

Torquay. Found in great abundance on Fucus, which was covered with Sertularia pumila, on the Breakwater at Babbacombe (Elwes, Journ. M.B.A., vol. 8, 1908, p. 201).

Autolytus punctatus de St. Joseph: Ann. Sci. Nat. Zool. I. 1886, p. 233.

Plymouth. Not uncommon on Queen's Ground and on the Rame-Eddystone and Looe-Eddystone trawling grounds.

Breeding: Specimens with stolons were taken from May to July. The breeding season probably extends considerably beyond these months.

This species has only been recorded from Dinard by de St. Joseph, from Boulogne by Malaquin (Syllidiens, Lille, 1893, p. 80), and from the west of Ireland by Southern (Proceed. R. Irish Acad. XXXI. 47, 1914, p. 42). It is easily recognised from de St. Joseph's description.

Autolytus Edwarsi de St. Joseph: Ann. Sci. Nat. Zool. I. 1886, p. 235.

Plymouth. This species is common in dredgings from Duke Rock and the rocky ground immediately south of the Breakwater. It appears to often live in tubes attached to the fronds and roots of Laminaria.

Breeding: Specimens with stolons were found from March to June and the breeding season probably extends beyond these months.

The species, which is well defined, has only been recorded by de St. Joseph from Dinard, by Malaquin (Syllidiens, Lille, 1893, p. 80) from Boulogne, and by Southern (Proceed. R. Irish Acad. XXXI. 47, 1914, p. 43) from the west of Ireland.

Autolytus prolifer (0. F. Müller): de St. Joseph, Ann. Sci. Nat. Zool. I. 1886, p. 238. Langerhans, Zeits. Wiss. Zool. XXXII. 1879, p. 575 .

Plymouth. Two specimens from Millbay Pit dredgings and one from dredgings from the rocky ground south of the Breakwater.

Breeding: Specimen in May had one stolon. In July a female had many eggs in the body segments.

The pharynx has ten large equal teeth, which according to Langerhans and de St. Joseph is characteristic of this species. The body 
is more robust than that of $A$. Edwarsi or $A$. punctatus and the living worms were picked out as distinct from the other species found here, on account of their form and movements, before the pharynx was examined. I agree with Southern that many of the records of this species in the literature are unreliable.

Autolytus Lugens de St. Joseph: Ann. Sci. Nat. Zool. I. 1886, p. 234.

Plymouth. Three or four specimens in dredgings from Queen's Ground and Millbay Pit.

Breeding: In January and February the stolon was just beginning to form ; in July a large stolon was well developed.

The specimens agreed with de St. Joseph's description. The massive black tentacles and dorsal cirri of the first segment were very conspicuous. The anal cirri had the same form, and the pharynx has 16 equal teeth. I have found no other record of the species except that by de St. Joseph, who took it at Dinard.

Autolytus inermis de St. Joseph: Ann. Sci. Nat. Zool. I. 1886, p. 237.

Plymouth. Occasional specimens have been taken on the principal dredging grounds in the Sound, as well as on the trawling grounds between Plymouth and the Eddystone and Eddystone and Looe. The specimens all had the characteristic colour.

Breeding: With stolons in December, January, April, May and June. One specimen in August had no stolon.

Torquay. One specimen (Elwes, Journ. M.B.A., vol. 8, 1908, p. 202). Malaquin (Syllidiens, Lille, 1893, p. 76) makes a new genus, Autolytides for this species, in which the pharynx has a plain border, without teeth of any kind.

Myrianida pinnigera (Montagu): McIntosh, Mon. Brit. Ann. II. 1, 1908, p. 229. Malaquin, Syllidiens, Lille, 1893, Plate I, etc., as $M$. fasciata Milne-Edwards.

Plymouth. Frequently met with in Plymouth Sound (w.G.); dredgings from Millbay Channel, Asia and Queen's Ground (т.v.н., R.A.T., E.J.A.) ; amongst Ascidians and sponges from the piles at Millbay Dock (R.A.T., E.J.A.).

Salcombe. On the shore at the Salstone and dredged in the channel to the west of the Salstone (Journ. M.B.A., vol. 6, 1900, p. 190).

Procerastea halleziana Malaquin: Recherehes sur les Syllidiens, Lille, 1893, p. 81, Pl. XI. Figs. 1-14, Pl. VIII. Fig. 26.

Plymouth. Six specimens were obtained from amongst Ascidians from a raft moored in Cawsand Bay, September 30th, 1914.

Breeding: The specimens bore no stolons, but in one specimen three of the middle segments were considerably enlarged. 


\section{HESIONID屏.}

Magalia perarmata Marion and Bobretzky: Annél. Golfe Marseille, 1875, p. 54. McIntosh, Mon. Brit. Ann. II. 1, 1908, p. 136.

Plymouth. Not uncommon in dredgings from Millbay Channel, Asia Shoal, Queen's Ground and Duke Rock. From trawl material, Rame-Eddystone ground. From scrapings from piles at Millbay Dock.

Torquay. Common among Laminaria roots (Elwes, Journ. M.B.A., vol. 8,1908 , p. 350).

Oxydromus propinquUs Marion and Bobretzky : Annél. Golfe Marseille, 1875, p. 51, as Gyptis propinqua. de St. Joseph, Ann. Sci. Nat. Zool. V. 1887, p. 321.

Plymouth. Not uncommon in dredgings from near New Grounds Buoy from January to April.

Breeding: Females with well-developed eggs, January to April.

Ophiodronus flexuosus Delle Chiaje : McIntosh, Mon. Brit. Ann. II. 1, 1908, p. 117.

Plymouth. Three or four specimens have been obtained from the Looe-Eddystone trawling grounds.

Castalia punctata (0. F. Müller): McIntosh, Mon. Brit. Ann. II. 1, 1908, p. 121.

Plymouth. Common in dredgings from Millbay Channel and Asia Shoal; occasionally from Duke Rock and Queen's Ground. A few specimens from rough grounds outside the Sound, e.g. 2 miles off Yealm Head and 2 miles S.W. by W. of Eddystone.

It was taken by Crawshay 17.5 miles S. $25^{\circ} \mathrm{W}$. of the Eddystone in 42 fathoms (Journ. M.B.A., vol. 9, 1912, p. 340).

Castalia fusca (Johnston): McIntosh, Mon. Brit. Ann. II. 1, 1908, p. 127.

Plymouth. On the shore under stones and amongst the roots of weeds from Drake's Island, Rum Bay and Mount Edgcumbe; from the piles at Millbay Dock. Amongst dredgings from Millbay Channel and Asia Shoal. Recorded in the previous list as Kefersteinia cirrata (Keferstein).

Torquay. Common under stones, especially at Meadfoot; also in Laminaria roots (Elwes, Journ. M.B.A., vol. 8, 1909, p. 350).

\section{AMPHINOMID虑.}

Spinther miniaceus Grube: McIntosh, Mon. Brit. Ann. I. 2, 1900, p. 232.

Plymouth. Half a dozen specimens living on a sponge dredged at Duke Rock, February 6th, 1906.

Breeding: Ripe females, depositing eggs. 
Euphrosyne foliosa Audouin and Edwards: McIntosh, Mon. Brit. Ann. I. 2, 1900, p. 234.

Plymouth. Occasional specimens in dredgings from Queen's Ground, Asia Shoal and Millbay Channel (т.v.H., R.A.T., E.J.A.). Eddystone Grounds.

One specimen 40 miles S. $24^{\circ}$ W. of Eddystone in 49 fms. (Crawshay, Journ. M.B.A., vol. 9, 1912, p. 341).

Ехмочтн. One specimen dredged amongst sponges (Journ. M.B.A., vol. 6, 1902, p. 318).

\section{APHRODITID开.}

Aphrodita aculeata Linn. : McIntosh, Mon. Brit. Ann. I. 2, 1900, p. 247.

Plymouth. On most of the fine-sand grounds off Plymouth, between 20 and 30 fms. (т.v.H., R.A.T., E.J.A.) S.S.W. of the Eddystone to 42 fms. (Crawshay, Journ. M.B.A., vol. 9, 1912, p. 340).

Salcombe. One small specimen from Millbay Sands (Journ. M.B.A., vol. 6,1900, p. 190).

Torquay. Thrown up on shore after heavy weather, especially at Anstey Cove and Tor Abbey Sands (Elwes, Journ. M.B.A., vol. 9, 1910, p. 59).

Hermione hystrix (Savigny): McIntosh, Mon. Brit. Ann. I. 2, 1900, p. 264.

Plymouth. Most frequently on gravel grounds in the neighbourhood of the Eddystone (Hodgson, Journ. M.B.A., vol. 6, 1900, p. 240) : occasionally on similar ground in about 20 fms. (R.A.T., E.J.A.).

S.S.W. of the Eddystone to $50 \mathrm{fms}$. on rough ground (Crawshay, Journ. M.B.A., vol. 9, 1912, p. 340).

Lepidonotus squamatus (Linn.): McIntosh, Mon. Brit. Ann. I. 2, 1900, p. 274.

Plymouth. Under stones and amongst weeds, Hydroids, Polyzoa, etc. : from low-tide mark to $30 \mathrm{fms}$. and over, common and widely distributed (Hodgson, Journ. M.B.A., vol. 6, 1900, p. 240).

S.S.W. of the Eddystone to 42 fms. (Crawshay, Journ. M.B.A., vol. 9, 1912, p. 340).

Salcombe. Dredged in the channel between the Salstone and Snape's Point, as well as in the channel in Salcombe Harbour. It was also obtained under the Marine Hotel (Hodgson, Journ. M.B.A., vol. 6, 1900, p. 190).

Torquay. Two or three under stones on Babbacombe Beach (Elwes, Journ. M.B.A., vol. 9, 1910, p. 59).

Lepidonotus clava (Montagu): McIntosh, Mon. Brit. Ann. I. 2, 1900, p. 280 .

Plymouth. Everywhere on the shore under stones, especially 
at extreme low water (Hodgson, Journ. M.B.A., vol. 6, 1900, p. 241): less frequently in dredgings from the Sound.

Exмоuтн. Not uncommon on the shore at Orcombe Rocks (Journ. M.B.A., vol. 6, 1902, p. 318).

Torquay. Occasionally found on all the beaches. Numerous specimens on a large buoy in Torquay Harbour (Elwes, Journ. M.B.A., vol. 9,1910 , p. 59).

Gattyana cirrosa (Pallas): McIntosh, Mon. Brit. Ann. I. 2, 1900, p. 285.

Plymouth. In dredgings from the neighbourhood of the Eddystone (Hodgson, Journ. M.B.A., vol. 6, 1900, p. 242). Yealm Sand Bank and east shore, commensal in tubes of Amphitrite Johnstoni.

Salcombe. Found on the shore living in the tubes of Amphitrite Johnstoni on the Salstone, south of Halwell Point and near the mouth of Salcombe Harbour (under Marine Hotel) (Hodgson, Journ. M.B.A., vol. 6, 1900, p. 190).

Eunoa nodosa (M. Sars): McIntosh, Mon. Brit. Ann. I. 2, 1900, p. 291.

One specimen from the stony ground off Prawle Point, in $30 \mathrm{fms}$. (Weldon, Journ. M.B.A., vol. 5, 1899, p. 478).

Lagisca extenuata (Grube): Fauvel, Résult. Camp. Sci. Monaco. Fas. XLVI. Annél. Polych. 1914, p. 62. McIntosh, Mon. Brit. Ann. I. 2, 1900, p. 298 as L. floccosa (Savigny)=L. propinqua Malmgren.

Plymouth. Between tide-marks and in dredgings throughout the whole area to $30 \mathrm{fms}$. (Hodgson, Journ. M.B.A., vol. 6, 1900, p. 247 as L. floccosa. At many stations S.S.W. of the Eddystone to about 50 fms. (Crawshay, Journ. M.B.A., vol. 9, 1912, p. 340, as L. floccosa).

Torquay. Fairly common under stones (Elwes, Journ. M.B.A., vol. 9, 1910, p. 59).

Note. Two varieties of this species occur in the Plymouth district. (1) A littoral and inshore variety, in which the elytron bears on its edge a few minute scattered cilia only, whilst the surface is covered with small tubercles slightly conical in shape and of fairly uniform size (a few being slightly larger than the rest) and has a number of large, brown, globular papillæ near the posterior border. (2) A deeper water variety found on the dredging and trawling grounds from 20 to $50 \mathrm{fms}$., in which the elytra bear on their edges a continuous row of minute cilia, almost spherical in shape. The surface of the elytron is covered with small tubercles as in the littoral variety, but scattered over the surface both towards the centre and especially towards the exterior and posterior borders a number of the tubercles are greatly enlarged, so that they stand out as strong conical spines. Those near the posterior border are the largest and their ends may appear rounded and swollen, but 
they do not attain the size of the large globular papillæ or the littoral form. This deeper water form approaches the $L$. rarispina of Malmgren, and was so entered in our previous lists. The spines do not, however, attain the length indicated in Malmgren's figures (Nordiska Hafs-Annulater, 1865. Tafl. VIII. figs. 2 and 2c).

With regard to the name of the species, Fauvel (loc. cit.) points out that Savigny's $L$. floccosa is described by its author as having sixteen pairs of elytra, and his description is too incomplete to fix even the genus to which it belongs. The first recognisable description of the present form is by Grube with the specific name extenuata. By this name it has been generally referred to in the literature or by its later synonym $L$. propinqua Malmgren.

The species referred to in previous lists by Hodgson and Elwes from Plymouth and Torquay (loc. cit.) as L. extenuata Grube, is I believe L. Elisabetha McIntosh.

Lagisca elisabeth A MeIntosh : Mon. Brit. Ann. I. 2, 1900, p. 303.

Plymouth. On the shore at Wembury Bay and Rum Bay, not uncommon. Probably the form referred to by Hodgson (Journ. M.B.A., vol. 6, 1900, p. 247) as L. extenuata Grube.

Torquay. Very common in roots of Laminaria and under stones (Elwes, Journ. M.B.A., vol. 9, 1910, p. 59). Southern has examined specimens from Torquay sent by Major Elwes and states that they are certainly this form (Proceed. R. Irish Acad. XXXI. 47, 1914, p. 51).

Harmothö̈ imbricata (Linn.) : McIntosh, Mon. Brit. Ann. I. 2, 1900, p. 314.

Plymouth. Between tide-marks amongst Laminaria roots on the Breakwater: amongst Hydroids, Polyzoa, etc., on Eddystone Grounds (Hodgson, Journ. M.B.A., vol. 6, 1900, p. 245).

This form seems to be rare at Plymouth, and I have not succeeded in re-finding it.

Harmothö̈ spinifera (Ehlers): McIntosh, Mon. Brit. Ann. I. 2, 1900 , p. 327.

Plymouth. Amongst dredgings from Millbay Channel, Queen's Ground, Asia Shoal, etc., and Yealm River: common (т.v.H., R.A.T., E.J.A.).

SALcombe. Dredged in the channel west of the Salstone, and between the Salstone and Snape's Point (Hodgson, Journ. M.B.A., vol. 6, 1900, p. 190).

Torquay. One specimen only found (Elwes, Journ. M.B.A., vol. 9, 1910 , p. 59).

Harmothö lunulata (Delle Chiaje): McIntosh, Mon. Brit. Ann. I. 2, 1900 , p. 342 .

Plymouth. A not uncommon tidal form. Found among roots of Laminaria on the Breakwater, and occasionally under stones 
near low water (Hodgson, Journ. M.B.A., vol. 6, 1900, p. 243). One specimen S.S.W. of Eddystone in 49 fms. (Crawshay, Journ. M.B.A., vol. 9,1912 , p. 341).

Salcombe. On the shore of the bay north of Pilworthy Point (Hodgson, Journ. M.B.A., vol. 6, 1900, p. 190).

Harmothö setosissima (Savigny): McIntosh, Mon. Brit. Ann. I. 2, 1900 , p. 345.

Plymouth. Occasionally found among Polyzoa (Cellaria) and Chatopterus tubes from the Eddystone Grounds (Hodgson, Journ. M.B.A., vol, 6, 1900, p. 244). S.S.W. of the Eddystone in 43-49 fms. (Crawshay, Journ. M.B.A., vol. 9, 1912, p. 341).

Salcombe. On the eastern shore of Salcombe Harbour (Hodgson, Journ. M.B.A., vol. 6, 1900, p. 190).

Harmothö areolata (Grube): McIntosh, Mon. Brit. Ann. I. 2, 1900, p. 349 .

Plymouth. Not uncommon on the Eddystone Grounds, where the dredge or trawl brings up masses of Polyzoa, Hydroids and Chcetopterus tubes (Hodgson, Journ. M.B.A., vol. 6, 1900, p. 244).

Harmothö̈ fraser-thomsoni MeIntosh: Mon. Brit. Ann. I. 2, 1900, p. 337.

Plymouth. Two specimens S.S.W. of the Eddystone in 4951 fms. (Crawshay, Journ. M.B.A., vol. 9, 1912, p. 341).

Harmothö marphys meIntosh: Mon. Brit. Ann. I. 2, 1900, p. 339.

Plymouth. Prof. McIntosh records this species from the galleries of Marphysa sanguinea from chinks in the rocks, Polperro (British Museum). It was found at Plymouth by Mr. R. A. Todd commensal with Marphysa sanguinea on the shore at Mount Edgcumbe.

A form which seems to resemble $H$. marphysa more closely than any other described species has been met with in fine sand in the Yealm Estuary. In one case the sand contained Amphitrite Johnstoni, in another Synapta inharens, and a definite association of the Harmothoë with the Synapta was actually observed in one instance.

Eqarne IMPAR (Johnston): McIntosh, Mon. Brit. Ann. I. 2, 1900, p. 353.

Plymouth. Common between tide-marks and amongst dredgings throughout the Plymouth area (т.v.H., E.J.A.): Eddystone Grounds (т.v.н.). S.S.W. of Eddystone in 40-42 fms. (Crawshay, Journ. M.B.A., vol, 9, 1912, p. 341).

SALCOMBE. Dredged in the channel between the Salstone and the mouth of Salcombe Harbour (Hodgson, Journ. M.B.A., vol. 6, 1900, p. 190).

Exмочтн. On the shore west of the mouth of Salthouse Lake (Journ. M.B.A., vol. 6, 1902, p. 318). 
Torquay. Rare. Recorded by Gosse from Anstey's Cove (Elwes, Journ. M.B.A., vol. 9, 1910, p. 59).

Scalisetosus communis (Delle Chiaje) : McIntosh, Mon. Brit. Ann. I. 2, 1900 , p. 372 .

Plymouth. On the shore at Mount Edgcumbe: amongst dredgings Millbay Channel and Asia Shoal (R.A.T., E.J.A.).

Fauvel considers that the name S. pellucidus (Ehlers) should be maintained for this species, as there is great doubt as to Delle Chiaje's species (Camp. Sci. Monaco, XLVI. 1914, p. 47).

Scalisetosus assimmis (McIntosh) : McIntosh, Mon. Brit. Ann. I. 2, 1900 , p. 377.

Plymouth. Among spines of Echinus esculentus from Mewstone and Eddystone Grounds (т.v.H., R.A.T., E.J.A.).

Malmgrenia castanea, MeIntosh : Mon. Brit. Ann. I. 2, 1900, p. 379.

Plymouth. Commensal on the surface of Spatangus purpureus, near the mouth of the Echinoderm : not uncommon (т.v.H., E.J.A.).

Halosydna gelatinosa (M. Sars): McIntosh, Mon. Brit. Ann. I. 2, 1900 , p. 384.

Plymouth. Frequently met with on the shore under stones and amongst dredging and trawling material throughout the area, including the Eddystone Grounds.

One specimen taken by Crawshay S.S.W. of the Eddystone in 49 fms. (Journ. M.B.A., vol. 9, 1912, p. 341).

Torquay. One specimen under a stone at Babbacombe Beach (Elwes, Journ. M.B.A., vol. 9, 1910, p. 60).

Polynoe scolopendrina Savigny Auct.: McIntosh, Mon. Brit. Ann. I. 2, 1900, p. 389. Marenzeller, Zur Kenntniss der adriatischen Anneliden. Sitzb. math-nat. Cl. Wien. 69, 1874, p. 420 as $P$. Johnstoni.

Plymouth. Commensal in tubes of Polymnia nebulosa on the shore at Mount Edgcumbe. In dredgings from Asia Shoal.

Eddystone Grounds (Hodgson, Journ. M.B.A., vol. 6, 1900, p. 249).

The specimens commensal with Polymnia nebulosa are large (6 to 7 centimetres long) and the colour tends, especially in spirit, to dark olive green. Those from dredgings in the Sound are smaller $(2-3 \mathrm{~cm}$.) and the colour is light brown. The elytra of the two sides nearly or even quite meet in the middle line in both cases. The dorsal bristle bundles are well developed. Three rows of dorsal tubercles on the posterior segments are very marked.

Polynoe CRAssipalpa Marenzeller: Zur Kenntniss der adriatischen Anneliden. Sitzb. math-nat. Cl. Wien. 69, 1874, p. 412.

Plymouth. Occasional specimens are met with in dredgings from Plymouth Sound.

When the two are seen side by side there can be no doubt that 
Marenzeller was right in separating this form from the $P$. scolopendrina Savigny of Johnston and other authors. In $P$. crassipalpa the body is much more slender and the dorsum is more strongly pigmented, the dark brown colour being arranged in a characteristic pattern. The posterior part of the ventral surface is also strongly pigmented. The elytra are small, to quote Savigny "separated by an interval equal to their breadth, the two rows thus leaving all the middle of the back uncovered; but the elytra of each row mutually overlap a little" (Syst. des Annélides, p. 25). This character and the complete absence of tubercles on the uncovered, posterior part of the dorsum give the species a quite characteristic appearance to the naked eye or under a low power lens. The bristles of the dorsal bundle in the typical foot are few, two or three only in one specimen examined by me, six in Marenzeller's specimens, and spinous rows are little developed on them. The ventral bristles as well as other details of the worm are well described by Marenzeller. The latter author, however, in my opinion, attaches undue importance in distinguishing the species of this genus to the relative lengths of the median tentacle, palps and tentacular cirri, especially as these have apparently been noted both by himself and by other authors only on preserved specimens. The palps especially seem to be subject to considerable and very variable degrees of contraction under the influence of preservatives. In a well preserved specimen which shows little sign of contraction I find the median tentacle just a little longer than the palps, and the dorsal tentacular cirri about the same length as the median tentacle. The palps taper gradually to a point and are not shaped as in Marenzeller's figure, which seems to have been drawn from a specimen in which they were much contracted.

Although I have not much doubt that Savigny's description applies to the present species it is impossible to be quite certain on the point, and it therefore seems better to use $P$. scolopendrina for the other form, which has been known under that name for half a century, and to call the present one $P$. crassipalpa, the name under which it was first clearly described by Marenzeller.

Lepidasthenia argus Hodgson: Journ. M.B.A., vol. 6, 1900, p. 250.

SALCombe. Found in the tubes of Amphitrite Edwardsi, on the shore between Salcombe town and Sandhill Point (under Marine Hotel) (т.v.H.).

The species has since been taken on many occasions in the same locality and under the same conditions as originally described by Hodgson. It has never been found elsewhere.

Acholö̈ Astericola (Delle Chiaje) : McIntosh, Mon. Brit. Ann. I. 2, 1900, p. 397.

In the ambulacral groove of Astropecten irregularis: common (т.v.H., R.А.т., Е.J.А.). 
Sthenelais воA (Johnston): McIntosh, Mon. Brit. Ann. I. 2, 1900, p. 408.

Plymouth. Common in sand between tide-marks, Rum Bay, Drake's Island, Mount Edgeumbe, Wembury Bay, Yealm River (т.V.H., R.A.T., E.J.A.) : occasionally amongst dredgings from Millbay Channel and Asia Shoal (т.v.H., E.J.A.): Mewstone Grounds (т.V.н.).

Salcombe. On the Salstone and near the mouth of the harbour, between the Ferry House and Millbay; never numerous. Dredged in the channel between Salstone and Snape's Point (Journ. M.B.A., vol. 6, 1900, p. 191).

Exмочтн. One specimen in the channel; never met with on the shore (Journ. M.B.A., vol. 6, 1902, p. 318).

Torquay. Not uncommon in the sand at Tor Abbey Sands (Elwes, Journ. M.B.A., vol. 9, 1900, p. 60).

Sthenelais limicola, Ehlers: McIntosh, Mon. Brit. Ann. I. 2, 1900, p. 417.

Plymouth. One specimen in a coarse townet attached to the Otter-trawl, 5 miles W.S.W. of Rame Head. One specimen dug in the sand bank in the upper part of the Yealm River.

Sigalion mathilde Audouin and Edwards: McIntosh, Mon. Brit. Ann. I. 2, 1900, p. 427.

Teignmouth. One specimen obtained in the sand below Shaldon Bridge.

Pholö̈ minuta (Fabricius): McIntosh, Mon. Brit. Ann. I. 2, 1900, p. 437.

Plymouth. Common amongst dredging and trawling material over the whole Plymouth area, including Eddystone Grounds. Especially abundant in Millbay Channel and on Asia Shoal.

Torquay. The most numerous of all the Torquay Aphroditidæ, inhabiting especially the Laminarian zone (Elwes, Journ. M.B.A., vol. 9, 1910, p. 60).

\section{PHYLLODOCID屃.}

Notophyllum foliosum (Sars): McIntosh, Mon. Brit. Ann. II. 1, 1908, p. 46.

Plymouth. Frequent in dredgings from all the grounds in the Sound, and often met with on all the dredging and trawling grounds outside, including the Eddystone Grounds.

In the previous list this species was wrongly named Eulalia obtecta Ehlers.

Torquay. One from Livermead (Elwes, Journ. M.B.A., vol. 8, 1909, p. 349). 
Eulalia bilineata (Johnston) : McIntosh, Mon. Brit. Ann. II. 1, 1908, p. 51.

Plymouth. Frequent amongst dredgings from the Sound, especially from Millbay Channel and Asia Shoal. Dredged off Yealm Head. Amongst roots of Laminaria from Cawsand Bay.

Eulalia aurea Gravier: Recherches sur les Phyllodociens, Bull. Sci. France et Belg. XXIX. 1896, p. 309.

Plymouth. Common on all the dredging grounds in Plymouth Sound. Occasional specimens are met with on most of the grounds near shore, e.g. off Yealm Head.

McIntosh (Mon. Brit. Ann. II. 1, 1908, p. 60) regards E. aurea as a variety of $E$. viridis. The general shape of the animal, the character of its movements, its size when mature and its usual habitat seem to mark it clearly from that form. The most striking difference is, however, the distinctive colour and colour pattern of each of the forms, which is very constant. In most respects $E$. aurea seems nearer to $E$. bilineata than to $E$. viridis.

Breeding: With eggs January to July (R.A.T., E.J.A.).

Torquay. On the shore, but not above the Laminarian zone (Elwes, Journ. M.B.A., vol. 8, 1909, p. 348).

Eulalia ornata de St. Joseph : Ann. Sci. Nat. Zool. V. 1888, p. 291.

Plymouth. In dredgings from the Sound, especially Millbay Channel and Asia Shoal. Much less frequent than E. aurea.

McIntosh (Mon. Brit. Ann. II. 1, 1908, p. 59) regards this form also as a variety of $E$. viridis. The well-marked colour pattern, its general shape and the character of its movements appear to me to justify doubts as to this conclusion.

Torquay. Fairly common, but not above the Laminarian zone (Elwes, Journ. M.B.A., vol. 8, 1909, p. 347).

Eulalia viridis (O. F. Müller) : McIntosh, Mon. Brit. Ann. II. 1, 1908, p. 55 .

Plymouth. Common on rocky shores in the Sound and on the coast. Its usual home seems to be amongst shore sea-weeds, to which the large gelatinous masses of green eggs are attached. It is, however, occasionally taken in dredgings from the Sound, especially in an immature state, and specimens have even been taken on the Eddystone Grounds.

Breeding: Eggs in January and February; abundant in May and June. None found at end of July or in August (A.J.S.).

Salcombe. From dredgings between Salstone and Snape's Point (Journ. M.B.A., vol. 6, 1900, p. 193).

Eхмочтн. Two specimens were obtained from Orcombe Rocks, at the mouth of the estuary (Journ. M.B.A., vol. 6, 1902, p. 320).

Torquay. Particularly abundant where the limestone rocks 
have been much eaten away from about half-tide mark downwards. It appears to like crawling about the damp rocks out of the water when the tide is low (Elwes, Journ. M.B.A., vol. 8, 1909, p. 347).

Eulalia tripunctata McIntosh: Mon. Brit. Ann. II. 1, 1908, p. 63. de St. Joseph, Ann. Sci. Nat. Zool. V. 1888, p. 285, as E. Claparedii.

Plymouth. Not infrequent in dredgings from Millbay Channel, Asia Shoal and occasionally Queen's Ground and Duke Rock. Found also on the outer grounds, e.g. off Yealm Head. Cawsand Bay, among Laminaria roots from the shore. Recorded in the former list as E. Claparèdi.

Breeding : May, eggs brick-red.

Eulalia punctifera (Grube): McIntosh, Mon. Brit. Ann. II. 1, 1908, p. 53 as Eulalia nebulosa, Montagu.

Plymouth. In dredgings from Millbay Channel, Asia Shoal and Yealm; on the shore at Mount Edgcumbe and in the Yealm Estuary.

Salcombe. Dredged in the channel between the Salstone and Snape's Point (Journ. M.B.A., vol. 6, 1900, p. 193).

Torquay. One specimen from Corbyn's Head (Elwes, Journ. M.B.A., vol. 8,1909 , p. 348 ).

Eulalia (Pterocirrus) macroceros (Grube): McIntosh, Mon. Brit. Ann. II. 1, 1908, p. 60.

Plymouth. Occasional specimens from dredging grounds in the Sound. A number also taken in dredging from 2 miles off Yealm Head.

Eulalia (Eumida) sanguinea Oersted: McIntosh, Mon. Brit. Ann. II. 1, 1908, p. 66.

Plymouth. Common and generally distributed in dredging material throughout the area, especially in inshore waters. Frequent amongst Laminaria roots from the shore.

Breeding: May to July ; eggs green, occasionally reddish.

The species shows considerable variety both of form and colour, and it seems probable that McIntosh has included under this name several forms which may prove to be distinct species.

One variety with alternate green and white bands on the dorsum (Eulalia Sp. B. McIntosh, l.c., p. 68), when seen alive appears to be specially distinct. Southern (Proceed. R. Irish Acad. XXXI. 47, 1914, p. 66) has also found this variety on the west coast of Ireland.

In the former list the present species was entered under the name of Eulatia pallida Claparède, with a reference to de St. Joseph's description.

ToRquay. Common among Laminaria roots (Elwes, Journ. M.B.A., vol. 8,1909 , p. 348).

Phyllodoce lamelligera (Gmelin): McIntosh, Mon. Brit. Ann. II. 1, 1908, p. 76. 
Between tide-marks Drake's Island: Breakwater : in dredgings from Millbay Channel, Asia Shoal, Duke Rock (т.v.H., в.J.A.).

Recorded in the former list as P. laminosa, Savigny.

Torquay. One light coloured individual under a stone at Hope's Nose, and another of normal colouring at Meadfoot (Elwes, Journ. M.B.A., vol. 8, 1909, p. 349).

Phyllodoce paretti (Blainville): McIntosh, Mon. Brit. Ann. II. 1, 1908 , p. 82.

Plymouth. Occasional specimens in dredgings from the Mewstone Ledge (E.J.A.) : off Stoke Point (s.P.).

Torquay. The head and about twenty segments of one from Corbyn's Head (Elwes, Journ. M.B.A., vol. 8, 1909, p. 349).

Phyllodoce maculata (Linn.): McIntosh, Mon. Brit. Ann. II. 1, 1908 , p. 89.

Plymouth. Common in dredgings from the Sound and inshore waters, being sometimes present in very large numbers. It seems to be much more abundant during the summer months than in winter. Large specimens which seem to be the same species were found in fine clean sand at Wembury Bay.

Breeding. January, February (w.G.): April to July. Eggs orange-brown or green (E.J.A.).

Exмоuтн. A form recorded as $P$. teres Malmgren from fine clean sand at Exmouth and from similar ground at Teignmouth I am now inclined to regard as the common P. maculata (Journ. M.B.A., vol. 6,1902 , p. 319 ).

Torquay. Common between tide-marks. Found amongst rocks and weeds, and also in the sand (Elwes, Journ. M.B.A., vol. 8, 1909, p. 348).

Phyllodoce rubiginosa de St. Joseph: McIntosh, Mon. Brit. Ann. II. 1, 1908, p. 92.

Plymouth. Frequent in dredgings from Millbay Channel, Asia Shoal and other parts of the Sound. Amongst dredge and trawl material from near the Eddystone.

Crawshay obtained several specimens S.S.W. of the Eddystone in 46-49 fms. (Journ. M.B.A., vol. 9, 1912, p. 341).

Eteone picta Quatrefages: McIntosh, Mon. Brit. Ann. II. 1, 1908, p. 100.

Plymouth. Occasional specimens from dredgings, Millbay Channel, Asia Shoal, Queen's Ground, Barn Pool. Some large specimens were found amongst roots of Laminaria from the shore at Cawsand Bay, and it was also taken on the shore at Wembury Bay.

Torquay. Small ones not uncommon amongst Laminaria roots (Elwes, Journ. M.B.A., vol. 8, 1909, p. 349). 
Eteone pusilla Oersted (nec Malmgren): Oersted, Ann. Dann. Consp. 1843, p. 30. Michaelsen, Poly. deutsch. Meere., Wiss. Meeresunters. II, 1897, p. 37.

Exмоuтн. In clean fine sand in the estuary (Journ. M.B.A., vol. 6, 1902, p. 319-320). Specimens 17 to $18 \mathrm{~mm}$. long, one of $17.5 \mathrm{~mm}$. having 94 pairs of parapodia.

Teignmouth. In clean fine sand in the estuary.

The head exactly resembles Oersted's figure. The anal cirri are large and swollen. They vary from cylindrical with a rounded end to slightly pear-shaped in preserved specimens, and very slight contraction in the preserving fluid would justify Oersted's description " papillis caudalibus subglobosis." They are altogether different from those figured by Malmgren, and from his description " cirri anales lineare-fusiformes elongati" (Nord. Hafs. Ann., 1865, p. 102, Tab. XV. Fig. 37).

Mrstides Limbata de St. Joseph: Ann. Sci. Nat. Zool. V. 1887, p. 310.

Plymouth. Dredged off the Mewstone in 15-16 fms. Female with dark green eggs in May (J.T.c.).

Not uncommon in dredgings from Asia Shoal and Queen's Ground (New Grounds). In dredgings from Yealm River.

A small median tentacle, as in Eulatia, is very distinct in some specimens when alive, but in the majority of specimens it is difficult, if not impossible to make out. In all other respects the form agrees with de St. Joseph's description.

\section{TOMOPTERID仺.}

Tomopteris helgolandica Greef: Apstein, Alciopiden und Tomopteriden der Plankton-Expedition, Kiel, 1900.

Plymouth. Not uncommon in townettings from the Channel.

\section{NEREID君.}

Micronereis variegata Claparède: McIntosh, Mon. Brit. Ann. II. 2, 1910, p. 261. Regnard, Mém. Soc. Zool. de France, XXVI. 1913, p. 91.

Plymouth. Amongst weeds and Corallina from the shore at Rum Bay. From weeds dredged in Cawsand Bay.

Torquay. Amongst red algæ and Lithothamnion from the rocks between Oddicombe and Babbacombe beaches (Elwes, Journ. M.B.A., vol. 8 , 1909, p. 350).

Leptonereis glauca Claparède: Ramsay, Journ. M.B.A. vol. 10, 1914, p. 244. 
Plymouth. From the piles of the wharf at Millbay Docks. Fairly numerous. Heteronereid males in February, females filled with ova in March (Ramsay, l.c.).

Torquay. One male Heteronereid in February at Oddicombe (Elwes, Journ. M.B.A., vol. 8, 1909, p. 351 as L. Vaillanti).

Nereis pelagica Linnæus: McIntosh, Mon. Brit. Ann. II. 2, 1910, p. 267.

Plymouth. Frequent amongst weeds on rocky shores and from dredgings in all parts of the Sound; also Wembury Bay and Yealm River (T.v.H., E.J.A.).

Eхмочтн. Dredged amongst masses of sponge (Halichondria panicea) in the main channel (Journ. M.B.A., vol. 6, 1902, p. 318).

Torquay. Extremely common in the roots of Laminaria. Heteronereids in January and February (Elwes, Journ. M.B.A., vol. 8, 1909 , p. 351).

Nereis zonata Malmgren: Fauvel, Résult. Camp. Sci. Monaco, Fas. XLVI. Annél. Polych. 1914, p. 177.

Plymouth. Common on the dredging and trawling grounds off Plymouth in depths of from 20-40 fms. Recorded previously as $N$. procera Ehlers (Journ. M.B.A., vol. 5, 1899, p. 481).

Dredged by Crawshay S.S.W. of the Eddystone in depths of 42-49 fms. (Journ. M.B.A., vol. 9, 1912, p. 342 as $N$. pelagica).

It seems to me probable that this is the species which Johnston calls Nereis fimbriata 0. F. Müller. He states that it inhabits the "coralline region," and he obtained it not only at Berwick Bay but also from Polperro (Cat. Worms. Brit. Mus. 1865, pp. 155 and 341).

Nereis (Perinereis) cultrifera Grube: McIntosh, Mon. Brit. Ann. II. 2, 1910, p. 280.

Plymouth. Common on the shores all around the Sound, Wembury Bay, Yealm Estuary, especially in muddy gravel. Young specimens frequent in dredgings.

Salcombe. Common all round the estuary excepting in very fine mud. Most common where soil is gravel mixed with sand and mud (Journ. M.B.A., vol. 6, 1900, p. 192).

Exмоuтн. One specimen only was found at Orcombe Rocks, quite at the mouth of the estuary (Journ. M.B.A., vol. 6, 1902, p. 318).

Torquay. Under stones, not very common, on the edge of the submerged forest at Tor Abbey Sands (Elwes, Journ. M.B.A., vol. 8, 1909, p. 352).

Nereis (Perinereis) Marioni Audouin and Edwards : McIntosh, Mon. Brit. Ann. II. 2, 1910, p. 295.

Plymouth. McIntosh (loc. cit.) records this species from Plymouth, probably in material sent from the Laboratory. I have not yet found it myself. 
Nereis (Praxithea) Schmard æi Quatrefages: McIntosh, Mon. Brit. Ann. II. 2, 1910, p. 291. de St. Joseph, Ann. Sci. Nat. Zool. V. 1888, p. 263, and XX. 1895, p. 215 as N. irrorata Malmgren.

Plymouth. Not uncommon in coarse sand and gravel between tide-marks, Drake's Island, Mount Edgcumbe, Jennycliff (rare), Wembury Bay, Yealm Estuary south shore. Small specimens amongst dredgings from Queen's Ground and Asia Shoal. Recorded in previous list as $N$. irrorata.

Salcombe. Common in muddy gravel under the Marine Hotel. Also found on the east side of the harbour, and one specimen in Kingsbridge Estuary south of Halwell Point (Journ. M.B.A., vol. 6, 1900 , p. 191, as N. irrorata).

Exмоuтн. One specimen from Orcombe rocks at the mouth of the estuary (Journ. M.B.A., vol. 6, 1902, p. 319, as N. irrorata).

Torquay. Occasionally under stones at Petit Tor Bay and Babbacombe Beach; amongst roots of Zostera at Corbyn's Head (Elwes, Journ. M.B.A., vol. 8, 1909, p. 352).

Nereis (Platynereis) Dumerilin Audouin and Edwards: McIntosh, Mon. Brit. Ann. II. 2, 1910, p. 302.

Plymouth. Small specimens are common on all the dredging grounds of the Sound, the largest specimens coming from Queen's Ground. In dredgings from Yealm River. Occasional specimens are obtained from the shores of the Sound and from Millbay Docks.

Torquay. Small individuals very common amongst algæ from rock pools (Elwes, Journ. M.B.A., vol. 8, 1909, p. 351).

Nereis (Hediste) diversicolor O. F. Müller: McIntosh, Mon. Brit. Ann. II. 2, 1910, p. 312.

Plymouth. Common in the mud flats of the Tamar and Plym estuaries, seldom in the Sound; found only where the density of the water is low.

SALCombe. Numerous only in a small gully traversed by a stream of fresh water which runs into Southpool Lake. 'Occasional specimens found in other parts of the harbour (Journ. M.B.A., vol. 6, 1900 , p. 193).

Ехмочтн. Very common in the upper parts of the estuary where the density of the water is low (Journ. M.B.A., vol. 6, 1902, p. 319).

Nereis (Eunereis) Longissima Johnston: McIntosh, Mon. Brit. Ann. II. 2, 1910, p. 325.

Plymouth. Occasional specimens in fine sand between tidemarks on Drake's Island and Mount Edgcumbe shore. Recorded by Cunningham from a mud-bank in the Cattewater near Oreston.

The Heteronereis stage is sometimes very numerous swimming in the Cattewater, the largest numbers being reported from near 
Laira Bridge. It has also been reported as numerous in the Hamoaze. It generally swims at night.

SALcombe. In fine muddy sand, especially abundant south of Garston Point and on the south side of the bay immediately below Halwell Point (Journ. M.B.A., vol. 6, 1900, p. 192, where further details as to its habitat and habits are given).

Exмочтн. One specimen on Bullhill Bank and one from the mud north of Salthouse Lake (Journ. M.B.A., vol. 6, 1902, p. 319).

Nereis (Neremepas) fucata Savigny: McIntosh, Mon. Brit. Ann. II. 2, 1910 , p. 336.

Plymouth. In shells of Buccinum undatum inhabited by Eupagurus Bernhardus: Mewstone Grounds, Rame-Eddystone, Looe-Eddystone and Eddystone Grounds.

Found by Crawshay at two positions S.S.W. of Eddystone in 42-47 fms., associated with Anapagurus lavis (Journ. M.B.A., vol. 9, 1912, p. 342).

S. Pace records a specimen from Yealm River.

Breeding. May (w.G.).

Salcombe. From a Hermit Crab on Millbay Sands (Journ. M.B.A., vol. 6,1900, p. 193).

Exмоuтн. In a shell inhabited by $E$. Bernhardus at Orcombe Rocks (Journ. M.B.A., vol. 6, 1902, p. 318).

Torquay. In whelk shells thrown up on shore (Elwes, Journ. M.B.A., vol. 8, 1909, p. 351).

\section{NEPHTHYDID丑.}

Nephthys CæCA (O. F. Müller) : McIntosh, Mon. Brit. Ann. II. 1, 1908, p. 8 .

Plymouth. Large specimens on sandy shores, especially Drake's Island, Rum Bay and Yealm Sand-bank (т.v.H., R.A.т., E.J.A.).

Salcombe. Only on the banks near the mouth of the harbour, being most numerous on the eastern side (Journ. M.B.A., vol. 6, 1900, p. 193).

Exмочтн. Several large specimens from Bullhill Bank (Journ. M.B.A., vol. 6, 1902, p. 319).

Nephthys Hombergi Lamarck: McIntosh, Mon. Brit. Ann. II. 1, 1908, p. 17.

Plymouth. Shore between tide-marks especially in sand, Drake's Island, Rum Bay, Jennycliff Bay, Bovisand, Wembury Bay, Whitsand Bay, Yealm River (R.A.T., E.J.A.) : dredged on Mewstone Amphioxus Ground (R.A.T.) and Eddystone Grounds (т.у.н.).

Salcombe. One of the commonest shore Polychætes in Sal- 
combe Estuary. On all grounds except finest mud (Journ. M.B.A., vol. 6,1900, p. 193).

Exмouth. Common in sand and muddy sand all over the estuary (Journ. M.B.A., vol. 6, 1902, p. 319).

Torquay. Common in sand at Tor Abbey Sands and Livermead. In dirty, muddy sand in the inner harbour of Torquay (Elwes, Journ. M.B.A., vol. 8,1909 , p. 350).

Nephthys CIRrosa Ehlers: McIntosh, Mon. Brit. Ann. II. 1, 1908, p. 36 .

Plymouth. In sand between tide-marks, Drake's Island and Yealm Estuary.

ExмочтH. In considerable numbers on grounds where the soil was fine clean sand, but did not occur in any other localities (Journ. M.B.A., vol. 6, 1902, p. 319).

Torquay. In clean sand in company with $N$. Hombergi, but not quite so numerous (Elwes, Journ. M.B.A., vol. 8, 1909, p. 350).

\section{EUNICID庄.}

Staurocephalus rubrovittatus Grube: McIntosh, Mon. Brit. Ann. II. 2,1910 , p. 353.

Plymouth. Frequent in dredgings from Millbay Channel, Queen's Ground, Asia Shoal, Duke Rock. Also taken 2 miles off Yealm Head.

Torquay. One specimen at an unusually low spring tide at Corbyn's Head (Elwes, Journ. M.B.A., vol. 9, 1910, p. 61).

Staurocephalus ciliatus (Keferstein) : Ehlers, Borstenwürmer, 1868, p. 424.

Plymouth. Recorded once from Queen's Ground dredging. No further specimens have been obtained since the one entered in the former list. The specimen has four eyes, an anterior pair of large eyes and a posterior pair of small ones, as described by Ehlers and Keferstein. In this respect it differs from the S. ciliatus of McIntosh (Mon. Brit. Ann. II. 2, 1910, p. 359), which is described as having two eyes, black, large and distinct.

Staurocephalus Pallidus Langerhans: Zeit. wiss. Zool. XXXIII. 1879, p. 300. McIntosh, Mon. Brit. Ann. II. 2, 1910, p. 362 and p. 363 .

Plymouth. Recorded once from Asia Shoal dredging. In the former list it was stated that the species " resembles $S$. ciliatus Kef., excepting for absence of eyes." This should have read " excepting for the absence of the posterior pair of eyes." The specimen, as McIntosh (l.c. p. 362) who examined it points out, has two very distinct eyes situated near the base of the tentacles. As regards the 
eyes, therefore, the specimen does not differ from the S. ciliatus with two eyes described by McIntosh; it does differ, however, from the S. citiatus described by Keferstein and Ehlers, which has four eyes. It agrees with $S$. pallidus Langerhans, which has two eyes. The correct synonymy of the two species, if indeed they are really distinct, can only be settled by further research.

Ophryotrocha pUERILIS Claparède and Mecznikow: McIntosh, Mon. Brit. Ann. II. 2, 1910, p. 364.

Plymouth. Frequently met with in dredgings from the Sound, especially from Asia Shoal. Sometimes very numerous in dredgings from the Cattewater. Often common in the Laboratory tanks.

Breeding: August (w.G.). Spawned in tanks, May (A.J.s.).

Torquay. Frequent on the sides of glass vessels containing roots and pieces of rock. A small aquarium was found to be swarming with this species (Elwes, Journ. M.B.A., vol. 9, 1910, p. 61).

Lumbriconereis fragilis O. F. Müller : McIntosh, Mon. Brit. Ann. II. 2, 1900 , p. 372.

Plymouth. Two specimens (both incomplete) from a depth of 47-49 fms. S.S.W. of the Eddystone are provisionally referred to this species by Crawshay (Journ. M.B.A., vol. 9, 1912, p. 342).

Southern (Proceed. R. Irish Acad. XXXI. 47, 1914, p. 85) thinks that $L$. fragitis 0 . F. Müller and $L$. impatiens Claparède may prove to be identical.

Lumbriconereis Latreilli Audouin and Edwards: McIntosh, Mon. Brit. Ann. II. 2, 1910, p. 376.

Plymouth. Shores of the Sound between tide-marks (Drake's Island, Mount Edgcumbe, Rum Bay) ; amongst dredgings from Millbay Channel, Asia Shoal, Queen's Ground, Yealm River and Eddystone Grounds.

Salcombe. A number of specimens on the west side of the harbour under the Marine Hotel. A few were found in other parts of the estuary (Journ. M.B.A., vol. 6, 1900, p. 191).

Torquay. Three or four in rather coarse gravel on Babbacombe Beach (Journ. M.B.A., vol. 9, 1910, p. 61).

Lumbriconereis impatiens Claparède: McIntosh, Mon. Brit. Ann. II. 2, 1910, p. 379.

Plymouth. Occurs in dredge and trawl material from the Rame-Eddystone, Looe-Eddystone and Mewstone Grounds, especially from gravel; very abundant on Queen's Ground in the spring of 1903.

Arabella (Maclovia) iricolor (Montagu): McIntosh, Mon. Brit. Ann. II. 2, 1910, p. 395.

Plymouth. Occasional specimens at low-water mark on the shores of the Sound and Wembury Bay. 
Salcombe. In muddy gravel on the west side of the Salstone and in sand near the mouth of the harbour. Interesting as being the locality in which Montagu chiefly collected (Journ. M.B.A., vol. 6, 1900 , p. 191).

Onuphis Britannica McIntosh: Mon. Brit. Ann. II. 2, 1910, p. 404.

Plymouth. On coarse shell-gravel grounds, in depths from 20 to $30 \mathrm{fms}$. off the Mewstone, off Stoke Point, South of Rame Head and off the Eddystone (E.J.A., R.A.T.).

Recorded in the former list as $O$. conchilega M. Sars.

Crawshay found it at several positions S.S.W. of the Eddystone in depths of 42-44 fms. (Journ. M.B.A., vol. 9, 1912, p. 342, as O. conchilega).

Hyalinecia sicula Quatrefages: McIntosh, Mon. Brit. Ann. II. 2, p. 417 (=H. bilineata Baird).

Pцyмоuтh. Dredged from shell-gravel ground off Yealm Head.

Hyalingcia tubicola (O. F. Müller): McIntosh, Mon. Brit. Ann. II. 2, 1910, p. 419.

Plymouth. Common on muddy-gravel grounds from 20 to 30 fms. : off the Mewstone, Rame-Eddystone and Eddystone Grounds (Е.J.A., R.A.T.).

Common and widely distributed on the area S.S.W. of the Eddystone at depths of 40-52 fms. (Crawshay, Journ. M.B.A., vol. 9, 1912, p. 342 ).

Eunice harassi Audouin and Edwards: Fauvel, Résult. Camp. Sci. Monaco, Fas. XLVI. Annél. Polych., 1914, p. 134. McIntosh, Mon. Brit. Ann. II. 2, 1910, p. 425 as E. fasciata Risso.

Pцyмоuтн. On the shore, Drake's Island, Rum Bay, Breakwater (R.A.T., E.J.A.) : Wembury Bay (E.J.A.). In dredgings from Duke Rock (w.G., т.v.H.) : Queen's Ground, Asia Shoal, Millbay Channel (R.A.T., E.J.A.) : south of Breakwater Fort (w.G.) : Rame-Eddystone Grounds.

Crawshay obtained three specimens S.S.W. of the Eddystone in 40-42 fms. (Journ. M.B.A., vol. 9, 1912, p. 342).

The synonymy of this species has recently been revised by Fauvel. He gives reasons for considering that the $E$. Harassii described by Claparède and Ehlers and probably also E. fasciata Risso are not the present species but $E$. torquata Quatrefages.

Eunice vittata Delle Chiaje: McIntosh, Mon. Brit. Ann. II. 2, 1910, p. 431.

Plymouth. McIntosh (loc. cit.) gives Plymouth as a locality on the authority of C. S. Bate, and Polperro on that of W. Baird. One specimen was dredged by Crawshay 16 miles S. $25^{\circ} \mathrm{W}$. of the Eddystone in 42 fms. (Journ. M.B.A., vol. 9, 1912, p. 342).

Marphysa sanguinea (Montagu): McIntosh, Mon. Brit. Ann. II. 2, 1910 , p. 442. 
PLymouth. Frequent on the shore in crevices of rock, especially on the bridge between Drake's Island and Mount Edgcumbe; also Rum Bay, Wembury Bay and Yealm Estuary (w.G., T.V.H., R.A.T., E.J.A.).

Salcombe. A few specimens were found in different parts of the harbour. Interesting as being the locality in which Montagu chiefly collected (Journ. M.B.A., vol. 6, 1900, p. 191).

Exмоuтн. One specimen from Orcombe Rocks (Journ. M.B.A., vol. 6,1902 , p. 318).

Marphysa Belli (Audouin and Edwards): McIntosh, Mon. Brit. Ann. II. 2,1910 , p. 448 .

Plymouth. On the shore between tide-marks, N. side of Drake's Island and Rum Bay: very common in the Zostera beds at the mouth of the Yealm River.

SALCOMBE. Specimens were obtained on the Salstone and near the mouth of Salcombe Harbour (under Marine Hotel) (Journ. M.B.A., vol. 6,1900 , p. 191).

Nematonereis unicornis (Grube): McIntosh, Mon. Brit. Ann. II. 2, 1910 , p. 453.

Plymouth. Between tide-marks, N. side of Drake's Island, Mount Edgcumbe and Yealm Sand-bank. Amongst dredgings from Queen's Ground, Asia Shoal and Millbay Channel.

Torquay. Fairly common in the limestone rocks at Babbacombe (Elwes, Journ. M.B.A., vol. 9, 1910, p. 61).

Lysidice punctata (Risso): McIntosh, Mon. Brit. Ann. II. 2, 1910, p. 456 .

Plymouth. Frequent in Plymouth Sound, on the shore between tide-marks (Rum Bay, Drake's Island), and in dredgings (Asia Shoal, Millbay Channel, Queen's Ground). On the shore at Wembury Bay and Reny Rocks. Dredged in Yealm River. Recorded in former list as L. ninetta Aud. and Edw.

Torquay. Small specimens 30 to $50 \mathrm{~mm}$. long, extremely common amongst Laminarian roots and limestone rocks (Elwes, Journ. M.B.A., vol. 9 , 1910 , p. 60 as $L$. ninetta).

\section{SPH止RODORID㞎.}

Ephesia Gracilis Rathke: McIntosh, Mon. Brit. Ann. III. 1, 1915, p. 47.

Plymouth. Frequently met with from all dredging grounds in the Sound and outside to the Eddystone Grounds. Most common Millbay Channel and Asia Shoal. Also found on the shore between tide-marks, Drake's Island and Mount Edgcumbe.

Single specimens dredged on a number of grounds S.S.W. of 
the Eddystone in 42-47 fms. by Crawshay (Journ. M.B.A., vol. 9, 1912, p. 343).

Torquay. Two or three from Meadfoot Beach (Elwes, Journ. M.B.A., vol. 9, 1910, p. 61).

Ephesia Peripatus Claparède : McIntosh, Mon. Brit. Ann. III. 1, 1915, p. 50 .

Torquay. Two specimens from Corbyn's Head (Elwes, Journ. M.B.A., vol. 9, 1910, p. 61).

Sphærodorum minutum (Webster and Benedict): Southern, Proceed. Roy. Irish Acad. XXXI. 47, 1914, p. 90.

Plymouth. Amongst Laminaria roots from Rum Bay; a number of specimens. From material trawled in the Cattewater.

\section{GLYCERID压.}

Goniada maculata Oersted: McIntosh, Mon. Brit. Ann. II. 2, 1910, - p. 462.

Plymouth. Occasional specimens from the shores of the Sound. Dredged in fine mud in the Sound.

Salcombe. A few specimens from the shore near the mouth of the harbour on both sides. (Journ. M.B.A., vol. 6, 1900, p. 194).

Glycera lapidum Quatrefages : McIntosh, Mon. Brit. Ann. II. 2, 1910, p. 477.

Plymouth. Between tide-marks Wembury Bay and Drake's Island (in shell gravel): dredged in shell gravel off the Mewstone and near Queen's Ground, not uncommon.

SALCombe. The species recorded as Glycera capitata dredged between the Salstone and Snape's Point is probably this form (Journ. M.B.A., vol. 6, 1900, p. 194).

Torquay. One specimen in the inner harbour of Torquay and one on the Babbacombe Beach (Elwes, Journ. M.B.A., vol. 9, 1910, p. 60).

Glycera siphonostoma Delle Chiaje: McIntosh, Mon. Brit. Ann. II. 2, p. 482 (=G. gigantea Quatrefages).

Plymouth. Between tide-marks, Drake's Island (w.G., R.A.т.). Mewstone Amphioxus ground.

Recorded in the former list as Glycera gigantea Quatrefages.

Glycera Alba Blainville: McIntosh, Mon. Brit. Ann. II. 2, p. 486 (=G. convoluta Keferstein).

Plymouth. The most common Glycera of the inshore waters. Between tide-marks Drake's Island, Jennycliff Bay, Yealm Estuary. In dredgings from Millbay Channel, Rame-Eddystone and Eddystone Grounds.

Recorded in the former list is $G$. convoluta Keferstein. 
Salcombe. Nowhere abundant. Two or three specimens from the shore in Salcombe Harbour (Journ. M.B.A., vol. 6, 1900, p. 194, as G. convoluta).

Exмочтн. Found occasionally on Bullhill Bank and on the gravel between Powderham and Starcross (Journ. M.B.A., vol. 6, 1902, p. 319, as G. convoluta).

Torquay. Fairly numerous in Tor Abbey Sands and at Livermead (Elwes, Journ. M.B.A., vol. 9, 1910, p. 60, as G. convoluta).

Glycera Goësi Malmgren: McIntosh, Mon. Brit. Ann. II. 2, 1910, p. 491 (=G. Mesnili de St. Joseph).

Plymouth. On the shore at Drake's Island, and in other parts of the Sound. Not uncommon. Dredged off Stoke Point and near the Eddystone.

This is the G. Mesnili of de St. Joseph. MeIntosh considers it the same as G. Goësi of Malmgren, but this seems to me open to doubt, if Malmgren's figure of the gill is correct. Fauvel (Résult. Camp. Sci. Monaco, 1914, p. 203) adopts the synonym G. Rouxii Audouin and Edwards.

\section{ARICIID屃.}

Aricia Cuvieri Audouin and Edwards: McIntosh, Mon. Brit. Ann. II. 2, 1910, p. 497.

Plymouth. Occasional specimens dredged off the Mewstone.

Aricia Latreilli Audouin and Edwards : McIntosh, Mon. Brit. Ann. II. 2,1910 , p. 502 .

Eхмочтн. Large specimens were moderately plentiful in the hard sand on the south of the Pole Sands (Journ. M.B.A., vol. 6, 1902, p. 321).

Torquay. In the sand at Tor Abbey Sands (Elwes, Journ. M.B.A., vol. 9,1910, p. 61$)$.

Scoloplos armiger (0. F. Müller) : McIntosh, Mon. Brit. Ann. II. 2, 1910, p. 510.

Plymouth. In dirty sand and between layers of shale at Rat Island (Hamoaze) (w.G.). In sand at Drake's Island, Rum Bay and . the Yealm Estuary.

Salcombe. A few specimens were found in the Zostera banks near the mouth of the harbour, on both the east and west sides (Journ. M.B.A., vol. 6, 1900, p. 194).

Ехмочтн. Not uncommon in sand on all the banks in the upper part of the estuary (Journ. M.B.A., vol. 6, 1902, p. 321). 


\section{SPIONID㭱.}

Nerine foliosa (Audouin and Edwards): McIntosh, Mon. Brit. Ann. III. 1, 1915, p. 142.

Pцyмоuтн. Wembury Bay (т.у.н.). In sand between tidemarks on the east side of Drake's Island, on the eastern side of the Sound, on Kingsand Beach (Cawsand Bay), Yealm Sand-bank, occasional specimens at each locality.

Recorded in the former list as $N$. coniocephala Johnston.

Salcombe. One specimen from the shore on the east side of the harbour (Journ. M.B.A., vol. 6, 1900, p. 194, as N. coniocephala).

Teignmouth. In sand in the estuary.

Exмоuтн. Several specimens were obtained in the sand west of Salthouse Lake and in the hard clayey mud to the north of it (Journ. M.B.A., vol. 6, 1902, p. 320, as N. coniocephala).

Nerine cirratulus (Delle Chiaje) : McIntosh, Mon. Brit. Ann. III. 1, 1915, p. 148.

Plymouth. In fine gravel between tide-marks on the eastern side of Plymouth Sound, occasional specimens only.

Salcombe. One specimen was obtained on the shore on the west side of the harbour, under the Marine Hotel (Journ. M.B.A., vol. 6,1910, p. 194).

Exмоuтн. Bullhill Bank and Cocklesands (Journ. M.B.A., vol. 6, 1902, p. 321).

Torquay. Tor Abbey Sands; not numerous (Elwes, Journ. M.B.A., vol. 9,1910, p. 62 ).

Scolecolepis vulgaris (Johnston): McIntosh, Mon. Brit. Ann. III. 1, 1915, p. 156 (=S. Girardi Quatrefages).

Plymouth. Occasional specimens only from Rum Bay.

Recorded in the former list as Scolelepis Giardi (de Quatrefages), a misprint for $S$. Girardi.

Torquay. At the west end of Tor Abbey Sands; rare (Elwes, Journ. M.B.A., vol. 9, I910, p. 62).

There is considerable difficulty as to the proper names to give to this and the following species. I have in this list followed McIntosh's monograph, though I feel some doubt as to whether the synonymy adopted by him is correct. Mesnil (Bull. Sci. France et Belg. XXIX. 1896) and de St. Joseph (Ann. Sei. Nat. Zool. XVII. 1894, p. 77) were both unable to satisfy themselves of the identity of $S$. vulgaris (Johnston) with S. Girardi (Quatrefages). Johnston no doubt had before him the common British species, inhabiting "the shore between tidemarks, ascending tidal rivers as far as the water is made brackish." Speaking of $N$. coniocephala he says, "This species inhabits our shores at low-water mark, and is seldom found with the preceding 
(i.e. N. vulgaris), which loves a station higher up " (Cat. Brit. Mus. 1865, pp. 200 and 201). In the south-west of England this account of the habitat applies not to $S$. Girardi, but to $S$. fuliginosa, which is the common shore and estuarine form, occurring in very large numbers, whereas isolated specimens of $S$. Girardi are only very occasionally found. On the west coast of Ireland, Southern (Proceed. R. Irish Acad. XXXI. 47, 1914, p. 96) found $S$. vulgaris of McIntosh $(=S$. Girardi of Mesnil) generally living in sand, rarely in Laminaria roots, and it was never abundant. S. fuliginosa was common locally in Blacksod Bay, but not widely distributed. Mesnil (loc. cit. p. 146) thinks it probable that the S. vulgaris of Cunningham and Ramage, which was abundant in the Firth of Forth, is $S$. fuliginosa, and that $S$. fuliginosa is the common species at Heligoland.

Scolecolepis fuliginosa (Claparède): McIntosh, Mon. Brit. Ann. III. 1, 1915, p. 160.

Plymouth. Very numerous in places in black mud at Rum Bay, Wembury Bay and Yealm Estuary.

Recorded in former list as "Scolelepis vulgaris Johnston (probably the same as S. fuliginosa Claparède, var. macrochata major of Mesnil)."

SALcombe. One small one dredged between Salstone and Snape's Point (Journ. M.B.A., vol. 6, 1900, p. 194, as Nerine vulgaris Johnston).

Torquay. Very numerous at west end of Tor Abbey Sands and at Livermead. In December numbers were found coiled up together under stones (Elwes, Journ. M.B.A., vol. 9, 1910, p. 62)

Scolecolepis (Laonice) cirrata (Sars): McIntosh, Mon. Brit. Ann. III. 1, 1915, p. 164.

Plymouth. MeIntosh (loc. cit.) gives Plymouth as a locality on the authority of Spence Bate and Brooking Rowe. I have not seen any specimens from this neighbourhood.

Spiophanes Bombyx (Claparède): McIntosh, Mon. Brit. Ann. III. 1, 1915 , p. 182.

Torquay. A few specimens at the east end of Tor Abbey Sands (Elwes, Journ. M.B.A., vol. 9, 1910, p. 62).

Aonides oxycephala (Sars): McIntosh, Mon. Brit. Ann. III. 1, 1915, p. 186.

Plymóuth. In the Zostera bed at low-water mark, eastern shore of Yealm mouth, very numerous. Yealm Sand-bank, occasional specimens. Rum Bay and Wembury Bay in crevices of shale. In sand at Wembury Bay.

Torquay. Numerous in rather foul mud under stones at Livermead (Elwes, Journ. M.B.A., vol. 9, 1910, p. 62).

Teignmouth. From sand in the estuary. 
Spio FILICornis Fabricius : McIntosh, Mon. Brit. Ann. III. 1, 1915, p. 172.

Plymouth. In fine, clean sand at Wembury Bay, at low tide.

The head of the living worm was conical, the point being used in attempts to burrow. The point could be bent downwards into the shape of a hook.

Pygospio elegans Claparède: McIntosh, Mon. Brit. Ann. III. 1, 1915, p. 189.

Plymouth. Forming tubes in very fine sand near the mouth of the Yealm River.

Breeding : March.

Ехмочтн. In the clean hard sand of the estuary. Not found on the more exposed Pole Sands (Journ. M.B.A., vol. 6, 1902, p. 320).

Teignmouth. Abundant in sand below Shaldon Bridge.

Pygospio seticonnis (Oersted): Mesnil, Bull. Sci. France et Belg. XXX. 1897, p. 85 ; Cunningham and Ramage, Trans. Roy. Soc. Edinburgh, XXXIII. 1888, p. 640.

Salcombe. Abundant on the shore under the Marine Hotel, forming long, slender tubes or galleries of mucus covered with sand grains (Journ. M.B.A., vol. 6, 1900, p. 194).

Exмоuтн. In clean hard sand in the estuary (Journ. M.B.A., vol. 6, 1902, p. 320).

The gills on the second setigerous segment are still very conspicuous and unmistakable in some of the preserved specimens which have recently been re-examined. Mesnil (loc. cit.) thinks that this form is not the Spio seticornis of Fabricius. Excepting for the presence of the gills on the second setigerous segment the species very closely resembles Pygospio elegans of Claparède.

Polydora ciliata (Johnston) : McIntosh, Mon. Brit. Ann. III. 1, 1915, p. 198.

Plymouth. Boring in limestone of the Breakwater and in limestone dredged in Millbay Channel. Boring in shells of Purpura and Littorina from Yealm Sand-bank. Frequently found in oyster shells.

Torquay. Very numerous in the small pools in the limestone boulders on the shore (Elwes, Journ. M.B.A., vol. 9, 1910, p. 62).

Polydora flava Claparède: McIntosh, Mon. Brit. Ann. III. 1, 1915, p. 205.

Plymouth. At Rum Bay and Rat Island (Hamoaze), common in crevices of shale (w.G.). In holes in limestone below the Laboratory and in dredgings from Yealm River.

Breeding: February (w.G.).

ToRquaY. Numerous on rocks and in pools (Elwes, Journ. M.B.A., vol. 9, 1910, p. 62).

Polydora caeca (Oersted): Mesnil, Bull. Sci. France et Belg. XXIX. 1896, p. 191. 
Plymouth. Eddystone Grounds (т.v.н.). On the shore at Rum Bay in crevices of shale.

Polydora hoplura Claparède: McIntosh, Mon. Brit. Ann. III. 1, 1915, p. 212.

Plymouth. Boring in limestone of the Plymouth Breakwater.

Magelona Papilliconnis Fr. Müller: McIntosh, Mon. Brit. Ann. III. 1,1915 , p. 223.

Plymouth. In fine sand near low-water mark at Jennycliff Bay, under Batten Castle, on the south shore of Yealm Estuary, and in Wembury Bay.

Larvæ in townets in July and August (E.J.A.) ; in September (Е.J.в.).

Torquay. One example at a very low spring tide on Tor Abbey Sands (Elwes, Journ. M.B.A., vol. 9, 1910, p. 62).

\section{DISOMID卌.}

Poeciloch ztus serpens Allen: Quart. Journ. Micr. Sci. vol. XLVIII. 1904, p. 79.

Plymouth. In sand at low tide south of Batten Castle; larvæ not uncommon in the plankton during the summer months.

Adults have since been found by Southern in sand on the shore of Lough Swilly (Proceed. Roy. Irish Acad. XXXI. 47, 1914, p. 105).

\section{CH出TOPTERID尼.}

Chatopterus variopedatus (Renier): McIntosh, Mon. Brit. Ann. III. 1, 1915, p. 120.

Plymouth. Common in muddy gravel on the Eddystone Grounds, Rame-Eddystone and Looe-Eddystone Grounds (E.J.A.) ; occasional specimens Duke Rock (т.v.H.); Asia Shoal (R.A.T.), Millbay Channel (R.A.T., E.J.A.) and Mewstone Echinoderm Ground (R.A.т.): Stoke Point Grounds (s.P.). A few specimens at a number of positions S.S.W. of the Eddystone in depths of $40-51$ fms. were taken by Crawshay (Journ. M.B.A., vol. 9, 1912, p. 343).

Larvæ in townettings July to October (w.G.).

Breeding. Ripe eggs and sperm in July (A.J.s., E.J.A.).

SAlcombe. Found on the shore at extreme low water on the west side of the Salstone and on the zostera bank near the mouth of the harbour on the western side. (Journ. M.B.A., vol. 6, 1900, p. 195).

Phylloch жtopterus anglica Potts: Proceed. Zool. Soc. London, 1914, p. 984.

Plymouth. From material brought in by trawlers from some. locality to the south of the Eddystone (Potts, loc. cit.). 


\section{AMMOCHARID正.}

Owenia fustFormis Delle Chiaje: McIntosh, Mon. Brit. Ann. III. 1, 1915, p. 356.

Plymouth. In fine sand near low-water mark at Jennycliff Bay and under Batten Castle.

SALCOMBE. In clean fine sand at Millbay (Journ. M.B.A., vol. 6, 1900, p. 195).

Teignmouth. In sand below Shaldon Bridge on the east side.

Torquay. Very numerous in Tor Abbey Sands (Elwes, Journ. M.B.A., vol, 9 , 1910, p. 62).

\section{CIRRATULID杫.}

Cirratulus (Audouinia) tentaculatus (Montagu): McIntosh, Mon. Brit. Ann. III. 1, 1915, p. 242.

Plymouth. Commoñ in gravel and sand just below high-water mark on all shores both inside and outside the Sound, excepting on open sandy beaches. Occasional small specimens dredged in shallow water amongst the roots of weeds.

SALCombe. Very common all over the estuary above half-tide mark, wherever the soil contains much mud mixed either with gravel or sand (Journ. M.B.A., vol, 6, 1900, p. 194).

Exмочтн. One specimen only was obtained from Orcombe Rocks quite at the mouth of the estuary. The entire absence of the species from the estuary itself is noteworthy (Journ. M.B.A., vol. 6, 1902, p.320).

Torquay. Numerous at Meadfoot, Hope's Nose and Tor Abbey Sands in rather foul mud (Elwes, Journ. M.B.A., vol. 9, 1910, p. 63).

Cirratulus cirratus (O. F. Müller) : McIntosh, Mon. Brit. Ann. III. 1, 1915, p. 249.

Plymouth. McIntosh (loc. cit. p. 250) gives Plymouth as a locality on the authority of Spence Bate and Brooking Rowe. I have obtained a number of specimens from crevices in the shale at Rum Bay, and from the shore below the Laboratory. Small specimens have been obtained from dredgings in the Cattewater and from scrapings of the piles in Millbay Dock.

Cirratulus norvegicus (Quatrefages): Southern, Proceed. Roy. Irish Acad, XXXI. 47, 1914, p. 107.

Plymouth. A specimen was obtained from crevices in the shale at Rum Bay. Mr. Southern has kindly confirmed the identification.

Dodecaceria concharum, Oersted: McIntosh, Mon. Brit. Ann. III. 1, 1915, p. 255.

Pцyмоuтн. Boring in limestone on Plymouth Breakwater, 
abundant; also in limestone below the Laboratory and from Millbay Channel.

Torquay. Very numerous in the limestone boulders at Babbacombe (Elwes, Journ. M.B.A., vol. 9, 1910, p. 63).

Heterocirrus viridis (Langerhans): McIntosh, Mon. Brit. Ann. III. 1, 1915, p. 261.

Torquay. Found occasionally in small pools in limestone rocks at Babbacombe (Elwes, Journ. M.B.A., vol. 9, 1910, p. 63).

Heterocirrus Caput-esocis de St. Joseph: McIntosh, Mon. Brit. Ann. III. 1, 1915, p. 263.

Torquay. Two or three found in small pools in limestone rocks at Babbacombe (Elwes, Journ. M.B.A., vol. 9, 1910, p. 63).

\section{TEREBELLID疋.}

Amphitrite gracilis Grube: de St. Joseph, Ann. Sci. Nat. Zool. XVII. 1894, p. 198.

Plymouth. Common in sand between tide-marks and between layers of shale in Rum Bay and at Mount Edgcumbe, Yealm Sandbank and Wembury Bay. Dredged at Millbay Channel and Eddystone Grounds.

Amphitrite Johnstoni Malmgren : de St. Joseph, Ann. Sci. Nat. Zool. V. 1898, p. 421.

Plymouth. In sand and gravel near low-water mark along the southern shore of the Yealm River; most common on the east shore where the stream divides (R.A.T., E.J.A.). Occasional specimens from Rum Bay.

Salcombe. Very abundant on the Salstone, especially on the north-east and south-east sides. Occasionally met with on the shore in all parts of the Kingsbridge Estuary and Salcombe Harbour, being abundant on the western shore near the mouth of the harbour (under Marine Hotel) (Journ. M.B.A., vol. 6, 1900, p. 195).

A мrнitrite Edwardsi Quatrefages : de St. Joseph, Ann. Sci. Nat. Zool. XVII. 1894, p. 186.

SALCOMbe. In the Zostera banks near the mouth of Salcombe Harbour, being especially abundant on the western side (under Marine Hotel). In the latter locality A. Johnstoni is also found, but is more abundant at a somewhat lower tidal level. A. Edwardsi was never found in the Kingsbridge Estuary, where A. Johnstoni was common.

The burrows of $A$. Edwardsi were generally occupied by the Polynoid Lepidasthenia argus (Journ. M.B.A., vol. 6, 1900, p. 196).

Terebella (Leprea) lapidaria Linn. : de St. Joseph, Ann. Sci. Nat. Zool. XVII. 1894, p. 202.

Plymouth. Common in crevices of shale at Rum Bay (r.A.t., E.J.A.).

NEW SERIES.-VOL. X. No. 4. MAY, 1915. 
Polymnia nebulosa (Montagu): de St. Joseph, Ann. Sci. Nat. Zool. XVII. 1894, p. 219.

Plymouth. Very common between tide-marks at Mount Edgcumbe (R.A.T., E.J.A.) : occasional specimens on the shore at Rum Bay and in dredgings from Millbay Channel, Asia Shoal, Queen's Ground and Yealm River (R.A.T., E.J.A.): Eddystone Grounds (т.v.н.).

Dredged by Crawshay at a number of stations S.S.W. of the Eddystone in 40-50 fms. (Journ. M.B.A., vol. 9, 1912, p. 343).

Salcombe. Dredged in the channel west of the Salstone (Journ. M.B.A., vol. 6, 1900, p. 197).

Exмочтн. A few specimens from Exmouth Dock and from dredging material from the sponge ground below the pier (Journ. M.B.A., vol. 6, 1902, p. 321).

Torquay. Occasional specimens at Corbyn's Head and in rocks between Oddicombe and Babbacombe beaches (Elwes, Journ. M.B.A., vol. 9 , 1910, p. 63).

Polymnia nesidensis (Delle Chiaje): de St. Joseph, Ann. Sci. Nat. Zool. XVII. 1894, p. 225.

Plymouth. Between tide-marks at Rum Bay, Mount Edgeumbe, Wembury Bay : dredged at Asia Shoal, Yealm River and Cawsand Bay.

One specimen dredged S.S.W. of the Eddystone by Crawshay at a depth of 49 fms. (Journ. M.B.A., vol. 9, 1912, p. 343).

Torquay. Very common in Laminaria roots, etc. (Elwes, Journ. M.B.A., vol. 9, 1910, p. 63).

Lanice conchilega (Pallas) : de St. Joseph, Ann. Sci. Nat. Zool. XVII. 1894, p. 211.

Plymouth. Common on sandy shores inside and outside the Sound; occasionally dredged on Queen's Ground; Eddystone Grounds (т.v.H., R.A.T., Е.J.A.).

Empty tubes were dredged by Crawshay S.S.W. of the Eddystone at depths from 42 to 49 fms. (Journ. M.B.A., vol. 9, 1912, p. 343).

SALcombe. Extremely abundant in patches of clean sand near the mouth of the harbour on both sides, and in sheltered parts of sandy bays outside the harbour. Found only occasionally in the upper parts of the estuary (Journ. M.B.A., vol. 6, 1900, p. 196).

Ехмочтн. Very common on the banks in the estuary, where there was a large proportion of gravel mixed with clean sand (Journ. M.B.A., vol. 6 , 1902, p. 321 ).

Torquay. Numerous on Tor Abbey Sands, especially at the east end (Elwes, Journ. M.B.A., vol. 9, 1910, p. 63). 
Nicolea venustula (Montagu)? de St. Joseph, Ann. Sci. Nat. Zool. XVII. 1894, p. 207. Marenzeller, Sitzb. Kg. Akad. der. Wiss. zu Wien, Bd. 89, 1884, p. 195.

English Channel. Seven specimens obtained 32 miles S. of Start Point (40-43 fms.).

Dredged by Crawshay at a number of stations S.S.W. of the Eddystone at depths of 42-50 fms. (Crawshay, Journ. M.B.A., vol. 9, 1912, p. 343).

These specimens from the deeper water of the Channel all have 17 bundles of bristles on each side.

The difference between this and the next species (Nicolea zostericola (Oersted) Malmgren) is discussed by de St. Joseph and by Crawshay (loc. cit. p. 344). N. venustula as described by de St. Joseph has 17 setigerous segments, whereas $N$. zostericola as described by Malmgren has 15 only.

MeIntosh (Ann. Mag. Nat. Hist., vol. 15, 1915, p. 20) describes $N$. venustula as having 15 bristle-bundles on each side, which would make the form described by him agree with $N$. zostericola.

Fauvel (Résult. Camp. Scient. Monaco, Fasc. XLVI. Annél. Polych. 1914, p. 299) has found both the form with 15 setigerous segments and that with 17 such segments. He considers them as the same species and adopts the name $N$. venustula (Montagu).

Nicolea zostericola (Oersted): Malmgren, Nordiska Hafs-Annulater, Öfer. K. Vet. Akad. Förh., 1865, p. 381.

Plymouth. Common between tide-marks on Reny Rocks; less frequent on the north side of Drake's Island. Also obtained from dredgings in Yealm River.

This species has 15 bundles of bristles on each side, and so far has only been recognised from the shore and shallow inshore waters. For comparison with $N$. venustula see note to that species.

Thelepus cincinnatus (Fabricius): Marenzeller, Adriat. Annel. Sitzb. K. Akad. der Wiss. zu Wien, Bd. 89, 1884, p. 205.

Plymouth. Common on the trawling grounds in the neighbourhood of the Eddystone (20 to $40 \mathrm{fms}$.).

Obtained by Crawshay at a number of stations S.S.W. of the Eddystone in depths of 40 to 50 fms. (Journ. M.B.A., vol. 9, 1912, p. 344).

If the number of pairs of gills (gills on two segments) is taken as the main character of the species, rather than the shape of the uncini, which seems variable, the species most commonly met with is T. cincinnatus, and not T. setosus, Quatrefages, as entered in the former list. It is probable that $T$. setosus also occurs in small numbers, but the matter requires re-investigation.

Salcombe. It is doubtful whether the species found at Salcombe should be assigned to $T$. setosus or to $T$. cincinnatus (Journ. M.B.A., vol. 6,1900 , p. 197). 
Polycirrus caliendrum Claparède : de St. Joseph, Ann. Sci. Nat. Zool. XVII. 1894, p. 237.

Plymouth. Common in dredgings from all parts of the Sound, especially in Millbay Channel. Dredged also in Yealm River. Occasional specimens amongst weeds and Laminaria roots from the shore.

In the former list two species $P$. aurantiacus Grube and P. caliendrum Claparède were recorded. The specimens included under the former name were those which are generally of large size and of a bright scarlet red colour. They have, however, three large pairs of nephridia and three small pairs as in P. caliendrum. The typical specimens of $P$. caliendrum, which were referred to in the former list, are of various shades of yellow, some being quite pale. They have six pairs of nephridia arranged as in the bright red form. I am inclined to agree with Southern's suggestion (Proceed. R. Irish Acad. XXXI. 47, 1914, p. 127) that P. aurantiacus and P. caliendrum may be identical, in which case the name $P$. aurantiacus Grube should have precedence. McIntosh's recent description of $P$. aurantiacus Grube (Ann. Mag. Nat. Hist. XV. 1915, p. 33) would appear to apply to the species now under discussion, and he speaks of a red variety.

Salcombe. Both varieties dredged between Salstone and Snape's Point (Journ. M.B.A., vol. 6, 1900, p. 197).

Polycirrus hжmatodes (Claparède): de St. Joseph, Ann. Sci. Nat. Zool. XVII. 1894, p. 241.

Plymouth. Not uncommon in dredgings from the Sound, especially from Millbay Channel and Asia Shoal. It is much less numerous than $P$. caliendrum.

Lormia medusa (Savigny) : Malmgren, Nord. Hafs-Annul. 1865, p. 380, Pl. XXV ; Ann. Polych. 1867, p. 217, Pl. XIV.

Plymouth. Amongst shell gravel near low-water mark on the north side of Drake's Island; from the shore in Yealm River. Tubes dredged on Queen's Ground.

Terebellides Stremi, Sars: Malmgren, Nord. Hafs-Annul. 1865, p. 396.

Plymouth. One specimen dredged four miles S.W. by S. of Rame Head.

\section{AMPHARETID床.}

Melinna adriatica Marenzeller: Adriatische Anneliden. Sitzb. Akad. Wien, Bd. 69, 1874, p. 472.

Plymouth. Very common in soft mud in Plymouth Sound. Found both on the shore at low. water and also by dredging.

Salcombe. In fine mud in the upper parts of Salcombe and Kingsbridge Estuary in very great abundance. Probably the Sabella curta of Montagu (Journ. M.B.A., vol. 6, 1900, p. 197). 
Exмоuтн. Only a few scattered specimens were found in the estuary (Journ. M.B.A., vol. 6, 1902, p. 322).

Torquay. Two at extreme low water at Livermead amongst Zostera roots (Elwes, Journ. M.B.A., vol. 9, 1910, p. 64).

Amphicteis Gunneri Sars: Fauvel, Résult. Camp. Sci. Monaco, Fas. XLVI. Annél. Polych. 1914, p. 281.

Plymouth. One specimen dredged four miles S.W. by S. of Rame Head.

Recorded in the former list as $A$. curvipalea Claparède, which Fauvel has shown to be identical with $A$. Gunneri Sars.

\section{AMPHICTENID蓲.}

Pectinaria (Lagis) Koreni Malmgren: de St. Joseph, Ann. Sci. Nat. Zool. V. 1898, p. 405.

Plymouth. Common in sand near low-water mark south of Batten Castle.

SAlcombe. Two specimens recorded as $P$. belgica from the shore may be this species (Journ. M.B.A., vol. 6, 1900, p. 198).

Pectinaria (Amphictene) auricoma (Müller) : Malmgren, Nord. HafsAnnulat. 1865, p. 357.

Plymouth. Eddystone Grounds (т.v.н.).

Pectinaria (Petta) pusillla Malmgren: Nord. Hafs-Annul. 1865, p. 361. Fauvel, Résult. Camp. Sci. Monaco, Fasc. XLVI. Annél. Polych. 1914, p. 279.

Plymouth. Two specimens dredged by Crawshay S.S.W. of the Eddystone in 42 fms. (Journ. M.B.A., vol. 9, 1912, p. 346).

\section{CAPITELIID夿.}

Notomastus latericeus Sars : McIntosh, Mon. Brit. Ann. III. 1, 1915, p. 276.

Plymouth. On the shore in black, muddy sand near low-water mark in the upper parts of the Yealm Estuary. Occasional specimens from the shore at Rum Bay and Wembury Bay.

Salcombe. One of the commonest Polychrtes of the shores of the estuary. Especially abundant and large in the fine mud in the upper parts of the estuary (Journ. M.B.A., vol. 6, 1900, p. 194).

Torquay. Under stones, Corbyn's Head and Livermead (Elwes, Journ. M.B.A., vol. 9, 1910, p. 64).

Notomastus rubicundus Keferstein: Eisig, Die Capitelliden des Golfes von Neapel, 1887, p. 863.

Plymouth. In fine clean sand on the north and south shores 
of the Yealm Estuary, near the mouth. In fine clean sand at Wembury Bay.

Prof. McIntosh considers that these are young $N$. latericeus. The appearance of the living worms is, however, quite distinct, and both the habits and the habitat of the two forms are different. $N$. latericeus burrows by constantly protruding the proboscis and when examined alive it is continually performing this movement. In the case of N. rubicundus, although many specimens have been watched, I have never yet seen the proboscis protruded.

Capitella capitata (Fabricius): McIntosh, Mon. Brit. Ann. III. 1, 1915 , p. 280.

Plymouth. Common in black mud from between tide-marks, Wembury Bay and Rum Bay.

Heteromastus filfformis Claparède: Eisig, Die Capitelliden des Golfes von Neapel, 1887, p. 839.

Exмоuтн. A few specimens in the sand west of Salthouse Lake (Journ. M.B.A., vol. 6, 1902, p. 320).

\section{OPHELIID止.}

Ophelia BICornis Savigny : de St. Joseph, Ann. Sci. Nat. Zool. V. 1898, p. 380 .

Exмоuтн. Very abundant in clean sand on the Pole Sands. Occasionally met with on other sand-banks (Journ. M.B.A., vol. 6, 1902, p. 321).

A considerable number of specimens have recently been examined and they have been compared with typical specimens of $O$. limacina Rathke from the North Sea. The distinguishing characters described by de St. Joseph are remarkably constant and there is no doubt that the two species are quite distinct. The list of synonyms of $O$. limacina given by McIntosh (Mon. III. 1, 1915, p. 10) therefore requires revision in the sense indicated by de St. Joseph. In the first region of the body of $O$. bicornis there are 9 setigerous segments, then follow 15 setigerous segments bearing gills or dorsal processes, and behind these five setigerous segments without gills, and one achetous anal segment. A constant character of the species not mentioned by de St. Joseph is a lateral, vertical, glandular fold of skin, which lies immediately in front of the 9 th parapodium. The lips of the parapodia are much less strongly developed than in $O$. limacina and all the bristles are much shorter, more slender and inconspicuous. The lateral rows of pores immediately above the gills described by de St. Joseph in Ophelia neglecta Schneider, which are very conspicuous in the large specimens of $O$. limacina (ef. de St. Joseph, p. 379) are entirely absent in $O$. bicornis.

Ammotrypane aulogaster Rathke: McIntosh, Mon. Brit. Ann. III. 1,1915 , p. 15. 
Plymouth. Occasionally dredged in the Sound, and on the Mewstone shell gravel.

Polyophthalmus pictus Dujardin : McIntosh, Mon. Brit. Ann. III. 1, 1915, p. 21.

Plymouth. On the shore between tide-marks Wembury Bay (A.J.S.) ; occasionally found on all rocky shores amongst the weed and coralline of tide pools.

Torquay. Common amongst Corallines, etc., in rock pools (Elwes, Journ. M.B.A., vol. 9, 1910, p. 64).

\section{MALDANID正.}

Micromaldane ornithoch жta Mesnil : Bull. Sci. France et Belg. XXX. 1897, p. 146. Southern, Proceed. R. Irish Acad. XXXI. 47, 1914, p. 134.

Plymouth. Found once on the shore at Rum Bay.

Nicomache lumbricalis (Fabricius) var.: Arwidsson, Zool. Jahrb. Abt. Systematik. Suppl. 9, Hft. 1, 1907, p. 86.

Pцyмоuth. One specimen was obtained amongst trawled material from the Rame-Eddystone Ground.

The specimen is in three pieces, but no portion seems to be missing. Its total length would be about $260 \mathrm{~mm}$. There are 21 setigerous segments and three pre-anal achetous segments. The anal funnel resembles Arwidsson's figure. The anterior border of the head has not a broad, hemispherical outline, but is produced into a slight but distinct blunt projecting process. This is not the Nicomache maculata Arwidsson, which is the only British Nicomache recorded in recent publications by McIntosh and Southern.

Cemsicirrus neglectus Arwidsson: Proceed. Roy. Irish Acad. XXIX. B. 6,1911, p. 217.

Plymouth. In sand and amongst roots of Zostera at the mouth of the Yealm Estuary.

Salcombe. Common in the Zostera beds near the mouth of the estuary.

Heteroclymene robusta Arwidsson: Zool. Jahrb. Abt. Systematik. Suppl. 9, Hft. 1, 1907, p. 227.

Plymouth. Occasionally met with amongst trawled material from the Rame-Eddystone Grounds.

\section{ARENICOLID址.}

Arenicola marina Linnaeus: McIntosh, Mon. Brit. Ann. III. 1, 1915 , p. 59.

Plymouth. In fine sand between tide-marks at Rum Bay, 
Drake's Island, Mount Edgcumbe, Wembury Bay and Yealm River (т.v.H., R.A.T.; E.J.A.).

Post-larval stages of Arenicola in townettings in February (w.G., w.B.B.) and March (E.J.A.).

Salcombe. Common in all parts of the harbour in sand or muddy sand (Journ. M.B.A., vol. 6, 1900, p. 195).

Ехмочтн. Very abundant in sand and gravel in the estuary (Journ. M.B.A., vol. 6, 1902, p. 321).

Torquay. Common on Tor Abbey Sands (Elwes, Journ. M.B.A., vol. 9,1910, p. 64$)$.

Arenicola ecaudata Johnston: McIntosh, Mon. Brit. Ann. III. 1, 1915, p. 72.

Plymouth. With $A$. branchiatis near the bases of rocks in a deposit composed of sand and small stones (F.w.G.) ; Rum Bay, in sand and gravel around the rocks below the Laboratory (R.A.T.); Wembury Bay (R.A.т., E.J.A.) ; Drake's Island (т.v.н.).

Torquay. Under stones in gravel at Hope's Nose and Babbacombe Beach (Elwes, Journ. M.B.A., vol. 9, 1910, p. 64).

Arenicola branchialis Audouin and Edwards: McIntosh, Mon. Brit. Ann. III. 1, 1915, p. 78. Ashworth, Cat. Chætopoda Brit. Museum I. 1912 , p. 141.

Plymouth. With $A$. ecaudata near the bases of rocks in a deposit composed of sand and small stones (F.W.G.); Rum Bay, Wembury Bay, Drake's Island.

Recorded in the former list as $A$. Grubei Claparède.

Salcombe. One specimen only found in muddy gravel on the west side of the Salstone (Journ. M.B.A., vol, 6, 1900, p. 195 as A. Grubii).

\section{SCALIBREGMID留.}

Scalibregma inflatum Rathke: McIntosh, Mon. Brit. Ann. III. 1, 1915, p. 34.

Plymouth. In muddy gravel at low water on the southern shore of the Yealm River, just below the junction of the two rivers ; two specimens $10 / 9 / 00$. No further specimens of this species have been taken.

Sclerocheilus minutus Grube: McIntosh, Mon. Brit. Ann. III. 1, 1915 , p. 43.

Plymouth. This species was formerly frequently taken in Millbay Channel dredgings, and occasionally in dredgings from Asia Shoal and oft the Mewstone. During the last two or three years no specimens have been found in spite of special search for it. 


\section{CHLORH届MID屟.}

Strlariomes (Trophonia) plumosa (O. F. Müller): McIntosh, Mon. Brit. Ann. III. 1, 1915, p. 231.

Plymouth. In dredgings from Millbay Channel and Asia Shoal, occasional specimens. Also dredged off Stoke Point.

Flabelligera (Siphonostoma) affinis Sars: McIntosh, Mon. Brit. Ann. III. 1, 1915, p. 107.

Plymouth. Between tide-marks at Drake's Island (R.A.T., T.v.H., E.J.A.) ; Reny Rocks (R.A.T., E.J.A.) ; under Rame Head (т.v.H.) ; Wembury Bay (E.J.A., A.J.s.) ; in dredgings from Millbay Channel, Queen's Ground (R.A.T., т.v.н.); Mewstone Grounds (E.J.A., R.A.T.) ; on Echinus acutus (R.A.T.).

Torquay. Under stones at Corbyn's head (Elwes, Journ. M.B.A., vol. 9,1910, p. 64).

\section{SABELLID सE.}

Sabella pavonina (Savigny): de St. Joseph, Ann. Sci. Nat. Zool. XVII. 1894, p. 267.

Plymouth. Common on the shore in Yealm River and also found in Yealm dredgings. Common on the shore in the Cattewater, near the entrance to Hooe Lake. Looe-Eddystone, RameEddystone and Eddystone Grounds, common amongst hydroids and Cellaria.

Dredged by Crawshay S.S.W. of the Eddystone at a number of positions in depths of 40 to 51 fms. (Journ. M.B.A., vol. 9, 1912, p. 346).

Specimens from the deeper water are all small with the tube of very fine mud, compact and light coloured. Those on the shore attain a large size and the tube is much coarser.

Breeding: August and September (c.s.).

SALCOMBE. Very abundant on the shore at the Salstone, and on the mud in Kingsbridge Estuary south of Garston Point. Absent from the banks near the mouth of Salcombe Harbour (Journ. M.B.A., vol. 6,1900, p. 198). These estuarine specimens were of large size.

ToRquay. Large specimens from the inner harbour. (Elwes, Journ. M.B.A., vol. 9, 1910, p. 65).

Branchiomma vesiculosum (Montagu) : de St. Joseph, Ann. Sci. Nat. Zool. XVII. 1894, p. 300.

Plymouth. Occasional specimens on the shore, Yealm sandbank and Rum Bay (R.A.T.): Drake's Island, south shore of Yealm near the mouth, Barn Pool, and shore south of Batten Castle.

SALCombe. In Salcombe Estuary where the soil is composed of gravel, abundant. It is found at a higher tidal level than Sabella pavonina and Myxicola infundibulum. Most numerous on the 
Salstone and in the upper parts of Salcombe Harbour (Journ. M.B.A., vol. 6,1900 , p. 199).

Dasychone вомвyx (Dalyell): de St. Joseph, Ann. Sci. Nat. Zool. XVII. 1894, p. 309.

Plymouth. Amongst Laminaria roots from the shores of the Sound and amongst Ascidians from Millbay Dock. Occurs on all the dredging grounds in the Sound, and outside to Eddystone Grounds.

Dredged by Crawshay at a number of positions S.S.W. of the Eddystone in depths of 40-49 fms. (Journ. M.B.A., vol. 9, 1912, p. 346).

Potamilla reniformis (O. F. Müller): de St. Joseph, Ann. Sci. Nat. Zool. XVII. 1894, p. 292.

Plymouth. Large specimens from the shore at Rum Bay and Jennycliff Bay in crevices of shale. Occurs also attached to rocks below the Laboratory, at Wembury Bay and other rocky shores. Not uncommon in holes in limestone from Plymouth Breakwater.

Torquay. On the sides of a cave at Petit Tor (Elwes, Journ. M.B.A., vol. 9,1910, p. 65$)$.

Potammla Torelli Malmgren: de St. Joseph, Ann. Sci. Nat. Zool. XVII. 1894, p. 296.

Plymouth. Common in dredgings from Millbay Channel, Asia Shoal and Yealm River.

In the former list Potamilla incerta Langerhans, found in dredgings from the Yealm River, was recorded. Fauvel considers this form to be a young stage of $P$. Torelli.

Torquay. Common in small rock pools in the limestone rocks between Oddicombe and Babbacombe beaches (Elwes, Journ. M.B.A., vol. 9,1910 , p. 65$)$.

Bispira volutacornis (Montagu) : de St. Joseph, Ann. Sci. Nat. Zool. XVII. 1894, p. 286.

Plymouth. In cracks between rocks at extreme low-tide mark on Reny Rocks and in Jennycliff Bay.

Myxicola infundibulum (Renier): de St. Joseph, Ann. Sci. Nat. Zool. V. 1898 , p. 433.

Plymouth. Found occasionally on the shore. North side of Drake's Island (R.A.T.); Barn Pool (E.J.A.); Ram's Cliff Point (s.P.). SaLcombe. Very frequent on all parts of the Salstone and on the Zostera flat immediately to the south of Pilworthy Point. Occasional specimens in the lower parts of Salcombe Harbour (Journ. M.B.A., vol. 6, 1900, p. 199).

Mrxicola (Leptochone) asthetica Claparède: Annél. Chétop. Naples, Supplément, 1870, p. 150.

Plymouth. Common in dredgings from Millbay Channel and 
Asia Shoal. Occasional specimens in dredgings from all parts of

the Sound. From the shore at Rum Bay in crevices of shale.

Amphiglena mediterranea Leydig: de St. Joseph, Ann. Sci. Nat. Zool. XVII. 1894, p. 307.

Plymouth. Amongst Laminaria roots from the rocks below the Laboratory. In crevices of shale at Wembury Bay.

TorquAy. From roots of Laminaria and pieces of limestone rock (Elwes, Journ. M.B.A., vol. 9, 1910, p. 65).

Jasmeneira elegans de St. Joseph: Ann. Sci. Nat. Zool. XVII. 1894, p. 316.

Plymouth. Amongst dredgings from Duke Rock and Asia Shoal.

Torquay. From roots of Laminaria and pieces of limestone rock (Elwes, Journ. M.B.A., vol. 9, 1910, p. 65).

Fabricia sabella Ehrenberg: de St. Joseph, Ann. Sci. Nat. Zool. XVII. 1894, p. 319.

Plymouth. Very abundant amongst mud scraped from piles at Millbay Dock.

Breeding. February.

Torquay. Very common in little pools in the rocks at Babbacombe (Elwes, Journ. M.B.A., vol. 9, 1910, p. 65).

OrIa armandi Claparède: de St. Joseph, Ann. Sci. Nat. Zool. XVII. 1894, p. 321.

Plymouth. Amongst Ascidians from the piles at Millbay Dock.

Torquay. One specimen from Babbacombe rock pools (Elwes, Journ. M.B.A., vol. 9, 1910 p. 65 ).

Haplobranchus enstuarius Bourne: Quart. Journ. Micr. Sci. XXIII. 1883, p. 169.

Plymouth. In tide pools not far from the mouth of the Yealm (Buchanan, Rep. Brit. Assoc. 1892, p. 359).

\section{SERPULTD址}

Serpula vermicularis Linnæus: de St. Joseph, Ann. Sci. Nat. Zool. XVII. 1894, p. 328.

Plymouth. Occasional specimens in the Sound. In small numbers from Mewstone Grounds, Looe-Eddystone, Rame-Eddystone and Eddystone Grounds.

Obtained at a number of positions S.S.W. of the Eddystone in depths of 42 to 49 fms. (Crawshay, Journ. M.B.A., vol. 9, 1912, p. 346).

Large masses of this species were obtained by a diver somewhere in the Hamoaze and brought to the Laboratory.

Breeding. Specimens from Eddystone Grounds in August and September were ripe (c.s.). 
Torquay. On shells thrown up on the shore at Tor Abbey Sands (Elwes, Journ. M.B.A., vol. 9, 1910, p. 66).

Pomatoceros triqueter (Linnæus): de St. Joseph, Ann. Sci. Nat. Zool. XVII. 1894, p. 353.

Plymouth. Common, attached to shells and stones on all grounds from the shore to $30 \mathrm{fms}$.

Dredged by Crawshay at several positions S.S.W. of the Eddystone in depths of 42-51 fms. (Journ. M.B.A., vol. 9, 1912, p. 347).

Salcombe. Common in dredge material from Salcombe Harbour and the Kingsbridge Estuary (Journ. M.B.A., vol.6, 1900, p. 199).

Exмоuтн. Found only at Orcombe Rocks, at the mouth of the estuary (Journ. M.B.A., vol. 6, 1902, p. 322).

Torquay. Extremely common on stones (Elwes, Journ. M.B.A., vol. 9,1910, p. 66).

Hydromes norvegica Gunnerus: de St. Joseph, Ann. Sci. Nat. Zool. V. 1898, p. 440.

Plymouth. Common on stones and shells from the shore to 30 fms., increasing in abundance in the deeper water.

Dredged by Crawshay at a number of positions S.S.W. of the Eddystone in depths of 40-49 fms. (Journ. M.B.A., vol. 9, 1912, p. 347).

Breeding. August (c.s.).

Torquay. On a stone at Petit Tor Beach; numerous on buoys in Torquay Harbour (Elwes, Journ. M.B.A., vol. 9, 1910, p. 66).

Filograna implexa (Berkeley): de St. Joseph, Ann. Sci. Nat. Zool. XVII. 1894, p. 335 ; ditto, p. 340 as Salmacina Dysteri Huxley.

Plymouth. In quantity from Millbay Channel, from the piles of the Promenade Pier (E.J.A.) ; on piles at the entrance to Millbay Dock (R.A.T.) ; on the Breakwater (т.V.H.). Occasionally met with in all dredgings from the Sound and on the outer grounds to the Eddystone.

Recorded by Crawshay at three stations S.S.W. of the Eddystone in 42-43 fms. (Journ. M.B.A., vol. 9, 1912, p. 347).

The distinction given by de St. Joseph and others between Filograna and Salmacina is that the former has opercula, whilst the latter has not. McIntosh considers the two forms the same, a view which is accepted by Cunningham and Ramage (Trans. Roy. Soc. Edin. XXXIII. 1888, p. 673) and by Southern (Proceed. R. Irish Acad. XXXI. 47, 1914, p. 147). The Plymouth specimens, of which a considerable number have been specially examined, have been without opercula.

Breeding. July, August and September (c.s.).

SpIrorbis borealis Daudin : de St. Joseph, Ann. Sci. Nat. Zool. XVII. 1894 , p. 345. 
Plymouth. Common on weeds, especially Fucus, and on stones on all shores.

Salcombe. Common in dredge material from Salcombe Harbour and the Kingsbridge Estuary (Journ. M.B.A., vol. 6, 1900, p. 199).

Torquay. Very common on Fucus (Elwes, Journ. M.B.A., vol. 9, 1910, p. 66).

SpIRorbIs spirillum Linnæus : Caullery and Mesnil, Bull. Sci. France et Belg. XXX. 1897, p. 198.

Plymouth. Dredged by Crawshay at a number of positions S.S.W. of the Eddystone in $42-51 \mathrm{fms}$. It occurred commonly on Hydroids, especially on Sertularia abietina (Journ. M.B.A., vol. 9, 1912, p. 347).

Torquay. On Sertularia abietina thrown up on the shore (Elwes, Journ. M.B.A., vol. 9, 1910, p. 66).

Protula tubularia (Montagu): de St. Joseph, Ann. Sci. Nat. Zool. XVII. 1914, p. 362.

Plymouth. Found on Mewstone Grounds, Rame-Eddystone Grounds and Eddystone Grounds (R.A.T., E.J.A.).

Dredged by Crawshay at four positions S.S.W. of the Eddystone in depths of 42-49 fms. (Journ. M.B.A., vol. 9, 1912, p. 347).

Breeding. Females with ripe eggs from Eddystone Grounds in June (A.J.S.)., August and September (c.s.).

\section{HERMELLID归.}

Sabellaria alveolata (Linnæus): de St. Joseph, Ann. Sci. Nat. Zool. XVII. 1894, p. 160.

Plymouth. Common attached to rocks on sandy shores at Whitsand Bay.

Exмоuтн. Very common at Orcombe Rocks at the mouth of the estuary, forming the usual reef-like masses (Journ. M.B.A., vol. 6, 1902, p. 322).

Torquay. Very common on all the Torquay coast (Elwes, Journ. M.B.A., vol. 9, 1910, p. 66).

Sabellaria spinulosa Leuckart: de St. Joseph, Ann. Sci. Nat. Zool. XVII. 1894, p. 154.

Plymouth. Occasional specimens attached to shells, etc., from all dredging grounds in the Sound, and from outside dredging and trawling grounds to the Eddystone.

Found in small numbers at many positions S.S.W. of the Eddystone by Crawshay (Journ. M.B.A., vol. 9, 1912, p. 348).

Breeding. May (w.G.) ; September (E.J.A.).

Pallasia murata Allen: Journ. Mar. Biol. Assocn. vol. 7, 1904, p. 299.

Plymouth. Two or three specimens have been obtained from 
gravel off Stoke Point and from shell gravel near the Mewstone. Empty tubes are frequently found on the latter ground.

Crawshay obtained tubes or portions of tubes at a large number of positions S.S.W. of the Eddystone in depths of 40 to $50 \mathrm{fms}$. Living specimens were obtained at three positions, the largest number being at Position 17 , situated 23.3 miles S. $28^{\circ} \mathrm{W}$. of the Eddystone, at a depth of $45 \mathrm{fms}$., where portions of six worms were taken (Journ. M.B.A., vol. 9, 1912, p. 348). 